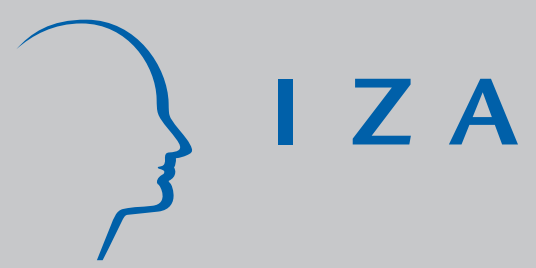

IZA DP No. 101

Employment and Wage Assimilation of Male First Generation Immigrants in Denmark

Leif Husted

Helena Skyt Nielsen

Michael Rosholm

Nina Smith

J anuary 2000 


\title{
Employment and Wage Assimilation of Male First Generation Immigrants in Denmark
}

\author{
Leif Husted \\ CIM \& Institute of Local Government Studies, København \\ Helena Skyt Nielsen \\ CIM, CLS \& Aarhus School of Business \\ Michael Rosholm \\ CIM, CLS \& Aarhus School of Business \\ Nina Smith \\ CIM, CLS, Aarhus School of Business \& IZA \\ Discussion Paper No. 101
January 2000
}

IZA

P.O. Box 7240

D-53072 Bonn

Germany

Tel.: +49-228-3894-0

Fax: +49-228-3894-210

Email: iza@iza.org

This Discussion Paper is issued within the framework of IZA's research area The Welfare State and Labor Markets. Any opinions expressed here are those of the author(s) and not those of the institute. Research disseminated by IZA may include views on policy, but the institute itself takes no institutional policy positions.

The Institute for the Study of Labor (IZA) in Bonn is a local and virtual international research center and a place of communication between science, politics and business. IZA is an independent, nonprofit limited liability company (Gesellschaft mit beschränkter Haftung) supported by the Deutsche Post AG. The center is associated with the University of Bonn and offers a stimulating research environment through its research networks, research support, and visitors and doctoral programs. IZA engages in (i) original and internationally competitive research in all fields of labor economics, (ii) development of policy concepts, and (iii) dissemination of research results and concepts to the interested public. The current research program deals with (1) mobility and flexibility of labor markets, (2) internationalization of labor markets and European integration, (3) the welfare state and labor markets, (4) labor markets in transition, (5) the future of work, (6) project evaluation and (7) general labor economics.

IZA Discussion Papers often represent preliminary work and are circulated to encourage discussion. Citation of such a paper should account for its provisional character. 


\section{ABSTRACT \\ Employment and Wage Assimilation of Male First Generation Immigrants in Denmark}

Labour market assimilation of Danish first generation male immigrants is analysed based on two panel data sets covering the population of immigrants and $10 \%$ of the Danish population during 1984-1995. Wages and employment probabilities are estimated jointly in a random effects model which corrects for unobserved cohort and individual effects and panel selectivity due to missing wage information. The results show that immigrants assimilate partially to Danes, but the assimilation process differs between refugees and non-refugees.

JEL Classification: J61, J71

Keywords: Immigrants, earnings and employment assimilation

Nina Smith

The Aarhus School of Business

Department of Economics

Fuglesangs Alleé 4

DK-8210 Aarhus V

Tel.: +458948 6413

Fax: +4586155175

Email: Nina@hha.dk

\footnotetext{
Thanks to Kræn Blume and Claus Houmann Frederiksen who have done part of the computational work. The project has been financed by the Danish Social Research Council (FREJA) and TSER. The authors want to thank members of the TSER network on 'Labour Demand, Education and the Dynamics of Social Exclusion' and seminar participants at IZA and CLS and the EALE conference 1999 for many helpful comments.
} 


\section{Introduction}

In 1980, there were about 135,000 immigrants in Denmark out of a population of about 5 million. This figure has increased rapidly since the mid 1980s and in 1998 there were 277,000 immigrants in Denmark, corresponding to 5.2 percent of the Danish population. These figures include 1st and 2nd generation of immigrants, where the latter group has been steadily increasing from 18,000 in 1980 to 70,000 in $1998 .{ }^{1}$ Compared to most other OECD countries, these figures are relatively low. In the 1960s and early 1970s, the dominant part of immigrants entering Denmark were tied movers and labour migrants, as the large demand for labour in the Danish economy attracted 'guest workers' mainly from Turkey and the former Yugoslavia. Another important group was immigrants from the other Nordic countries (Sweden, Norway, Finland and Iceland). Before 1973 the booming Western European economies attracted many guest workers, but after the first oil crisis in 1973 and the economic downturn which followed, the immigration pattern changed. As in many other European countries, the immigration of 'guest workers' stopped, while refugee immigration grew considerably, especially after the mid 1980s. ${ }^{2}$ Thus, the composition of immigrants concerning country of origin and reason for immigration has changed during the last decades.

Table 1 shows the composition of the stock of immigrants in Denmark in the years 1984, 1989 and 1995 which span the time period analysed in this study. It is evident from Table 1 that the relative importance of immigrants from other EU countries and North America has decreased substantially whereas the relative number of immigrants from 'refugee-countries' like Iran, Iraq, Sri Lanka, and individuals with no citizenship from Palestine has increased in both absolute and relative terms.

There is not much empirical research on the economic integration of immigrants to Denmark. In Pedersen (1996) and Schröder (1996), the migration between Denmark and other Nordic countries is analysed. In Hummelgaard et al. (1995), the labour market conditions for immigrants are analysed. Among other results, they find a significantly negative effect on the duration of unemployment from a variable representing years since migration. The only study which directly analyses the earnings capacity of immigrants to Denmark is found in the Ministry of Economics (1997). The results in this study indicate that there is evidence of earnings assimilation. The study is based on a cross-section sample of Danes and immigrants. There is no control for neither selectivity problems due to missing wage information on more than half of the sample of

\footnotetext{
${ }^{1}$ In this study we use the definition of a (first generation) immigrant given by Statistics Denmark and it is: An individual who is born in a country other than Denmark, and whose parents both have foreign citizenship or are born abroad is a first generation immigrant, see Statistics Denmark (1998) and Section 2. This definition includes immigrants who get a Danish citizenship. ${ }^{2}$ Immigration of guest workers was stopped by law in 1974. After this year only relatives to guest workers (tied
movers) were allowed to immigrate to Denmark.
} 
immigrants, nor for cohort differences between immigrants, see for instance Lalonde and Topel (1997), which may be important because the composition of the immigrants by country of origin has changed over time.

Table 1. Country of origin for the stock of first generation immigrants in Denmark.

\begin{tabular}{lccc}
\hline & 1984 & 1989 & 1995 \\
\hline & ------------ & percent & --------------- \\
Nordic countries & 16.3 & 11.9 & 9.9 \\
EU countries (12) & 24.3 & 19.4 & 17.2 \\
Turkey & 13.7 & 14.2 & 13.8 \\
Other European countries & 12.8 & 12.8 & 12.1 \\
Africa & 6.0 & 5.9 & 8.2 \\
North America & 4.2 & 3.6 & 2.8 \\
South \& Latin America & 2.8 & 2.1 & 2.2 \\
Sri Lanka, Iran, Iraq & 0.9 & 9.4 & 10.2 \\
Vietnam & 2.8 & 2.9 & 3.4 \\
Pakistan & 7.3 & 5.8 & 4.9 \\
No citizenship & 0.1 & 3.5 & 5.1 \\
Others & 8.7 & 8.6 & 10.3 \\
\hline Total & 100 & 100 & 100 \\
\hline Pct of population which are immigrants & \\
Pct of population with a foreign citizenship & & $3.5 \%$ & $4.3 \%$ \\
\hline
\end{tabular}

1. EU countries is defined as the $12 \mathrm{EU}$ members prior to the expansion in 1997.

2. Source: The data described in Section 5.

3. Source: Statistical 10-year review.

In this paper we analyse wage and employment assimilation of Danish refugee and non-refugee immigrants. We use a large register database of all male immigrants in Denmark covering each of the years 1984-95. The database includes information on a number of labour market characteristics of immigrants and information on country of origin, year of migration etc. The database does not include information on Danish language fluency and pre-immigration educational attainment. However, since the data set is a panel, we are able to control for unobserved heterogeneity by using panel data estimation techniques. As a consequence, we also control for cohort effects which are expected to be a serious problem, since the composition of immigrants to Denmark by country of origin has changed considerably during the last two decades.

Another major problem in many analyses of wage assimilation is to tackle the selectivity problems resulting from a high frequency of missing wage information, either because of nonparticipation, self-employment or other reasons. This problem turns out to be a very serious problem in the sample because the employment rate of immigrants, especially refugee immigrants, is very low. The econometric model handles this problem by estimating the wage 
and employment equations simultaneously and allowing for random effects in both the employment and wage equations. The model is estimated separately for refugee immigrants, nonrefugee immigrants, and native Danes. The results show that immigrants assimilate (at least partially) to Danes, but the assimilation process differs between refugees and non-refugees. Refugees have very low initial employment probabilities, but given that they succeed in getting a stable attachment to the labour market, their wage rates assimilate towards the wage level of Danes within a 10 year period.

The paper is organized as follows: Section 2 discusses hypotheses about wages and employment of immigrants to Denmark. Section 3 presents the assimilation model to be estimated. Section 4 discusses econometric issues, whereas Section 5 presents the data. Section 6 gives the estimation results, and Section 7 concludes the analysis.

\section{Two hypotheses on wages and employment of immigrants to Denmark}

The change in the composition of immigration over time toward refugees rather than labour immigrants is important for the study of the earnings capacity of immigrants. Refugee immigrants are often expected to have a lower earnings capacity in the country of destination compared to labour migrants who immigrate due to economic reasons. The argumentation is based on selectivity differences. Labour migrants are expected to be positively selected from the native country with respect to the earnings capacity in the immigrant country, see for instance Chiswick (1978). This may partly explain why many earlier studies found that the earnings of immigrants approached the earnings of native-born citizens and often exceeded the earnings of native-born citizens after a certain number of years. Another explanation of the observed wage assimilation found in earlier studies has been cohort effects because immigrants from older cohorts often had better labour market qualifications than immigrants from the cohorts that have migrated during the last decades, see Borjas (1994).

For refugee immigrants the situation is usually expected to be different from labour migrants since they are not necessarily positively selected with respect to earnings capacity in the immigrant country, see Chiswick and Hurst (1999). They may have more difficulties than nonrefugee immigrants with respect to speaking the language of the destination country and they may possess less education, or their education may be more difficult to use in the immigrant country compared to labour migrants. However, as discussed by Borjas $(1987,1999)$ and Chiswick (1999), there may also be other selection processes taking place. In countries like Denmark with a highly compressed wage structure and a fairly generous and universal welfare benefit system, there may be a negative selection of immigrants, since a compressed wage structure and the welfare schemes may attract mainly low-skilled workers. These negative selection mechanisms may exist for refugees as well as labour migrants. 
For immigrants entering Denmark, the language may cause special problems. As it is the case with other 'small-area-languages', very few immigrants, except immigrants from other Nordic countries, are able to speak the Danish language when they arrive in Denmark. ${ }^{3}$ Refugee immigrants may differ systematically from non-refugee immigrants with respect to the conditions of and motives for learning the Danish language. Especially tied movers who have family relations to Danes or to individuals who have stayed in Denmark during a period may learn the Danish language more easily than refugees with no relations to Denmark prior to migration. Further, if refugee immigrants differ from other migrants with respect to the length of their expected stay in Denmark, i.e. if they expect to stay for a shorter time, this may affect their investments in human capital and language fluency, see Dustman (1999). Individuals who expect to return to the country of origin invest less in language fluency and other human capital in the country of destination, especially if these investments are sunk cost when returning to the country of origin.

For both refugees, labour migrants and tied movers, the conditions for accumulating human capital in the host country may depend on the tightness of the labour market. Since the early 1970s, the overall unemployment rate in Denmark has been fairly high, and for immigrants the unemployment rate has been much higher than for Danish born individuals, as illustrated in Figure 1. The extremely high unemployment rates of immigrants may imply that human capital is not automatically accumulated by spending a given number of years in the new country. If the immigrant has not been able to get a firm attachment to the labour market and hence acquire labour market experience in the new country, the effect of having spent many years in the country may be a reduction (and not an improvement) of the earnings capacity. In the analyses presented in this study we are able to account for this when estimating assimilation models since we have exact information on accumulated employment experience since migration for immigrants.

Part of the explanation behind the large differences in the unemployment rates for Danish born and immigrants may be the compressed Danish wage structure. Compared to most other OECD countries, the wage dispersion in Denmark is fairly small, see OECD (1996). The high effective minimum wages mean that it is difficult for low-skilled workers to obtain employment. Because most of the immigrants have no usable education or experience when they arrive in Denmark, the high unemployment rates in Figure 1 may simply reflect the general shortage of jobs for lowskilled workers. The compressed wage structure and the high effective minimum wages covering virtually all sectors of the Danish labour market give less room for an assimilation process. If an immigrant succeeds in getting a job, the wage will typically be relatively high compared to Danish born workers, but it is fairly difficult to get large absolute wage increases over time

\footnotetext{
${ }^{3}$ See for instance Dustmann (1994), Chiswick and Miller (1995), and Dustmann and van Soest (1998) for analyses of the importance of language fluency on the earnings capacity among immigrants.
} 
because of the high starting wages. ${ }^{4}$ Therefore, for Denmark and other countries with high minimum wages, a large part of the assimilation mechanism lies in simply getting a job. ${ }^{5}$ Thus, we extend the traditional assimilation analyses of immigrants and analyse wage and employment assimilation jointly in this paper.

Figure 1. Unemployment rates for individuals with Danish and foreign citizenship

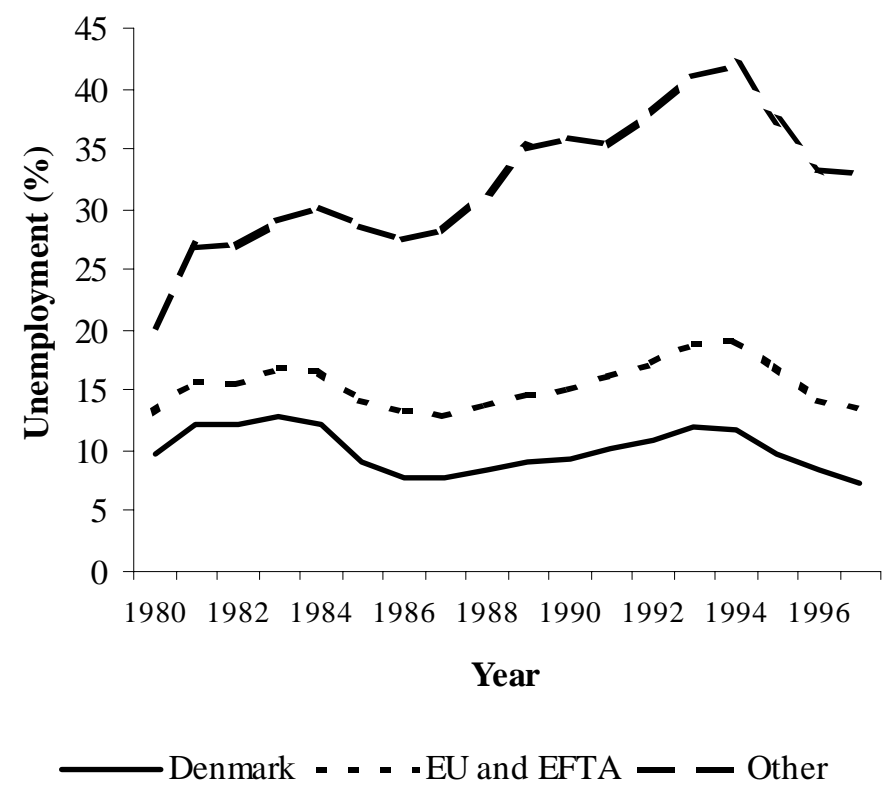

The high overall unemployment rates of Danish born as well as immigrants since the early 1970s may also have another effect on the earnings capacity of immigrants. The tightness of the labour market in the country of destination at the time of immigration might exert a permanent influence on the future labour market career of the immigrants because of a 'scarring effect'. As an example, immigrants from outside EU- and EFTA-countries who entered the Danish labour market in 1994 faced an overall average unemployment rate of about 40 percent for all immigrants from this area, see Figure 1. On the other hand, immigrants of 1986 where the unemployment rate was 25 percent may have experienced less difficulties. A similar hypothesis is relevant when the labour market career of the native born youth is studied. The effect of the overall tightness of the labour market may be a short-term effect which disappears over time, or it may be a long-term effect that follows the individual during the whole labour market career, see for instance Chiswick, Cohen and Zach (1997) and Chiswick and Miller (1999). In the

\footnotetext{
${ }^{4}$ See OECD (1996) where it is shown that the relative wage mobility is rather high in Denmark but measured in absolute terms, wage mobility is fairly low compared to other OECD countries because of the compressed Danish wage structure.

5 The same results are found for Sweden which also has a fairly compressed wage structure, see le Grand and Szulkin (1999).
} 
analyses presented below we test whether the labour market conditions at the year of entering the labour market has permanent effects on the wage and employment experience of immigrants as well as Danish born individuals.

To summarize, we want to test two hypotheses in this paper. The first hypothesis concerns whether there are differences in employment and wage assimilation patterns between refugee and non-refugee immigrants. To do this, we will split our sample of immigrants into refugee and nonrefugee immigrants. Our second hypothesis concerns the effects of labour market attachment on employment and wage assimilation patterns. We will address this question by including information on actual working experience in Denmark, and aggregate unemployment in Denmark in the year of immigration. In addition, we will estimate employment and wage equations jointly, thereby correcting for selectivity effects.

Table 2 shows the average wage rates and employment rates for male refugee and non-refugee immigrants in 1995. The group of non-refugees consists of labour migrants as well as tied movers because the Danish data on immigrants do not allow us to identify these two groups separately.

It is clear from Table 2 that there are large differences between refugee immigrants and nonrefugee immigrants, as well as differences within these groups with respect to the success that they experience in the Danish labour market. In general and as expected, refugee immigrants have much lower employment rates and earn less if they succeed in getting a job than nonrefugee immigrants. On average, only 42 percent of all male refugee immigrants aged 20-59 years are employed either as wage earners or self-employed. For non-refugee male immigrants this figure is 72 percent and for native men aged 20-59 years it is 89 percent. Immigrants, including refugee immigrants, from Europe (excl. Turkey) and North America seem to do much better in the Danish labour market with respect to employment and earnings capacity than immigrants outside these regions. Part of this evidence may be due to differences in the average number of years that the immigrants have spent in Denmark or other systematic differences between refugees and non-refugees. In the estimations presented below, we control for these differences. 
Table 2. The average hourly wage rate and employment rate in 1995. Male immigrants aged 2059 years. ${ }^{1}$

\begin{tabular}{|c|c|c|c|c|}
\hline Immigrant group: & Refugees & Non-Refugees & Refugees & Non-Refugees \\
\hline Nordic countries & - & 0.720 & - & 185.5 \\
\hline EU countries $(12)^{2}$ & - & 0.781 & - & 159.6 \\
\hline Turkey & - & 0.713 & - & 134.8 \\
\hline Other European countries & 0.603 & 0.723 & 150.7 & 148.7 \\
\hline Africa & 0.219 & 0.640 & $116.7 *$ & 134.6 \\
\hline North America & - & 0.707 & - & 182.0 \\
\hline South \& Latin America & 0.695 & 0.632 & 137.6 & 148.2 \\
\hline Sri Lanka, Iran \& Iraq & 0.390 & 0.659 & 122.3 & $145.4^{*}$ \\
\hline Vietnam & 0.599 & - & 123.1 & - \\
\hline Pakistan & - & 0.676 & - & 133.4 \\
\hline No citizenship & 0.259 & - & 127.3 & - \\
\hline Others & 0.293 & 0.669 & $121.0^{*}$ & 145.7 \\
\hline All immigrants & 0.421 & 0.720 & 129.2 & 153.8 \\
\hline Danish born & \multicolumn{2}{|c|}{0.891} & \multicolumn{2}{|c|}{156.8} \\
\hline
\end{tabular}

* Less than 100 observations with an observed wage.

1. Individuals who work less than 200 hours annually and those working as self-employed are excluded from the calculation of average wage rates due to measurement problems. The employment rate is defined as the number of individuals employed at least 200 hours annually as wage earners plus those working as self-employed, divided by the total number of immigrants in the group concerned.

2. EU countries is defined as the $12 \mathrm{EU}$ members prior to the expansion in 1997.

Source: See Section 5.

\section{Assimilation models}

The empirical model takes as starting point the classical analyses of earnings or wage assimilation as formulated in for instance Chiswick (1978). We extend these models by including explicit information on the labour market attachment of the immigrants since migration, i.e. whether they have been employed or not during the years after immigration.

The 'classical model' for analysing wage assimilation between immigrants and native born individuals is given by (ignoring possible polynomial terms of the explanatory variables) ${ }^{6}$

$$
\ln w_{i}=\alpha_{i}+\boldsymbol{X}_{i} \boldsymbol{\theta}_{i}+\delta_{i} A_{i}+\gamma_{i} Y S M_{i}+\varepsilon_{i}
$$

where $\ln w$ is the $\log$ hourly wage rate, $\boldsymbol{X}$ is a vector of socioeconomic variables, incl. educational

\footnotetext{
${ }^{6}$ In the estimations of both models we allow for non-linearities in the effects of age, experience and years since migration.
} 
indicators, which are assumed to affect the earnings capacity, $A$ is the age of the individual, YSM is the number of years spent in the country of destination and $\left(\alpha_{i}, \boldsymbol{\theta}_{i}, \delta_{i}, \gamma_{i}\right)$ is the parameter vector to be estimated. The subscript ' $i$ ' indicates 'immigrant'. For native born the model is

$$
\ln w_{n}=\alpha_{n}+X_{n} \boldsymbol{\theta}_{n}+\delta_{n} A_{n}+\varepsilon_{n}
$$

where the subscript ' $n$ ' indicates 'native born'. If $\delta_{i}+\gamma_{i}>\delta_{n}$ this is an indication that the wages of immigrant workers assimilate to those of native born workers, assuming that the wage level is lower for immigrants in the first year after immigration. We denote the model described by (1) and (2) as the 'Classical Model'.

Since we have rather precise information on whether the time since immigration has been spent as employed or as non-employed (either unemployed or out of the labour force), we are able to test whether the wage effect from years since migration, YSM, differs between years spent as employed in Denmark, EXPER, and years spent as non-employed in Denmark, YSM-EXPER:

$$
\ln w_{i}=\alpha_{i}+\boldsymbol{X}_{i} \boldsymbol{\theta}_{i}+\delta_{i} A_{i}+\gamma_{1 i} \text { EXPER }_{i}+\gamma_{2 i}(Y S M-E X P E R)_{i}+\varepsilon_{i}
$$

For Danish born individuals, a variable measuring the number of years of accumulated experience is added to (2) in the corresponding model which we denote the 'Experience Model'.

Traditionally, the main focus in the literature has been on wage assimilation. But as discussed in the previous section, the assimilation process may as well be a process of employment assimilation. The observed employment rates may of course reflect demand as well as supply conditions in the labour market. In this sense, the employment assimilation model is to be considered a reduced form model which reflects both sides of the labour market. However, since we restrict the analysis to men only and since we do not estimate working hours but only whether employed or not, we will assume that most of the explanations of the observed variation in employment rates among different groups of immigrants and Danish born men are due to demand side effects. ${ }^{7}$

\section{Econometric specifications}

Since data is in the form of an unbalanced panel (see Section 5) and we have potential sample selection problems, the appropriate empirical model is a panel data sample selection model. Such models have been examined and/or estimated by e.g. Hausman and Wise (1979), Ridder (1990), Verbeek and Nijman (1992), Vella and Verbeek (1994), Nijman and Verbeek (1996), Kyriazidou

\footnotetext{
${ }^{7}$ The wage assimilation process of immigrant women is analysed in Husted et al. (1999).. Hummelgaard et al. (1995) find large differences between immigrant men and women with respect to labour force participation and unemployment structure.
} 
(1997), and Vella (1998).

Ideally, the model is the following:

$$
\begin{aligned}
& y_{i t}^{*}=x_{i t} \beta+\alpha_{i}+\varepsilon_{i t} \\
& d_{i t}^{*}=z_{i t} \gamma+\eta_{i}+v_{i t} \\
& d_{i t}= \begin{cases}1 & \text { if } d_{i t}^{*}>0, \\
0 & \text { otherwise }\end{cases} \\
& y_{i t}=y_{i t}^{*} \cdot d_{i t}
\end{aligned}
$$

where $y^{*}$ denotes the $\log$ hourly wage, $d^{*}$ is a latent variable measuring the additional benefits of being employed (over not being employed), and $d$ is an indicator for being employed. However, since we include some individuals who are employed, but for whom we do not observe the hourly wage (such as the self-employed), we define an additional indicator, $c_{i t}$, taking the value 1 if the wage is observed, and 0 otherwise, that is, $d_{i t}$ is always 1 whenever $c_{i t}$ is 1 , but not vice versa. The last line of equation (4) above thus changes to $y_{i t}=y_{i t}^{*} \cdot c_{i t}$.

We make the following assumptions concerning the idiosyncratic error terms:

$$
\begin{gathered}
E\left[\varepsilon_{i t}\right]=E\left[v_{i t}\right]=0, \\
\left(\varepsilon_{i t}, v_{i t}\right) \sim \mathrm{N}(0, \Sigma), \text { where } \\
\Sigma=\left[\begin{array}{cc}
\sigma_{\varepsilon}^{2} & \rho \sigma_{\varepsilon} \\
\rho \sigma_{\varepsilon} & 1
\end{array}\right]
\end{gathered}
$$

In addition, we make the following assumptions regarding the random effects and their interactions with the idiosyncratic errors

$$
\begin{gathered}
E\left[\alpha_{i}\right]=E\left[\eta_{i}\right]=0 \\
\varepsilon_{i t}, v_{i t} \perp \alpha_{i}, \eta_{i}
\end{gathered}
$$

Regarding the random effects, we assume that they follow a discrete distribution with $2 \times 2$ points of support (and thus 4 associated probabilities).

The likelihood function is derived in Appendix B, which also contains a derivation of the expected value of the wage, conditional on working, which is needed for the calculation of 
wage assimilation profiles, see Section 6.

\section{Data}

The empirical analysis is based on two large data sets, originating from administrative registers. The first data set is a 10 percent sample of the Danish population (about 500,000 individuals) covering the period 1984-1995. The original sample is an unbalanced panel sample of individuals aged 15 years or more. Young individuals are added to the sample each year. Thus, besides being a panel, the sample is also representative for the population in each of the years. The other data set contains information on the entire population of immigrants in Denmark (about 250,000 individuals in 1995) for each of the years 1984-1995. The sample contains information on a very large number of demographic and labour market characteristics of the individuals and their families. Key variables used in this study are hourly wages, age, civil state, occupation, number of years of actual working experience, and level of formal education obtained in Denmark.

In the estimations presented below we do not use the total data sets available. Firstly, we restrict the samples to first generation immigrants and exclude second generation immigrants. We also restrict the sample to men only, because the employment and earnings conditions of immigrant women are considerably different from those of men. Further, the sample is restricted to individuals aged 20-59 years in order to avoid selection problems due to retirement. ${ }^{8}$ In addition, the sample has been restricted to individuals who are not currently in education. In the Appendix Table A1, mean values for a number of variables in the pooled data sets are shown. The group of immigrants is split into two groups, refugee immigrants and non-refugee immigrants. In the estimations presented below, we do not use the full sample of immigrants from these two groups. Two samples are selected randomly from the male population of immigrants, including 33 percent of all refugee immigrants and 13 percent of non-refugee immigrants. In total we use 45,000 observations for refugee immigrants and 49,000 observations for non-refugee immigrants. From the sample of Danish born individuals we have randomly selected 47,000 individuals.

A first generation immigrant usually has a foreign citizenship, but immigrants who have lived in the destination country for a sufficient number of years may have the option to convert citizenship to that of the destination country. An alternative criterion for defining immigrants may therefore be country of birth. However, foreign born individuals may have Danish parents who have only lived abroad for a shorter period. Therefore, information on own and parents' citizenship and birth country is used when defining whether an individual is considered to be an immigrant: A first generation immigrant is defined as an individual with birth country other than Denmark where both parents have foreign citizenship or are born abroad. If information on one

\footnotetext{
8 The official retirement age in Denmark was 67 until 1999 but due to an early retirement scheme (efterlønsordningen) which most of the labour force participants were eligible for, the actual average retirement age was 61-62 years in the period 1984-95.
} 
of the parents is missing but the other parent is full-filling the criteria, the individual is also defined as an immigrant. Finally, if there is no information on any of the parents then the individual is defined as a first generation immigrant if he is born abroad. Individuals who are applying for asylum are not included in the group of immigrants until they obtain a residence permit.

The hourly wage rate is measured in DKK and is inflated by the consumer price index (1995prices). The information on wages is based on annual earnings divided by annual hours employed. Thus, overtime payments and earnings in a second job are included in the average wage measure. If overtime work and the frequency of a second job vary systematically between immigrants and native-born, we may over- or underestimate the differences between the wage levels of immigrants and native-born individuals. Based on information on annual employment, we define the employment indicator, $d_{i t}$, which is 1 if the individual works more than 200 hours in a given year, and 0 otherwise. ${ }^{9}$

Employment and hourly wages are only observed for individuals who have been employed as wage earners during the year. Working hours and hourly wages are not observed for selfemployed individuals and assisting spouses. Self-employment is a very important economic state for many immigrants. ${ }^{10}$ However, since we are not able to get information on wages and working hours for this group based on register information, we treat all self-employed as being employed with an unobserved wage, that is, $d_{i t}=1$ and $c_{i t}=0$, where $c_{i t}$, as described in the previous section, is an indicator variable which assumes the value of 1 if the wage rate is observed and 0 otherwise.

The experience variable EXPER measures actual experience obtained by being employed as a wage earner in Denmark. This variable is based on the payments to a compulsory pension scheme, ATP. The ATP payments are a stepwise linear function of the number of hours employed during the week or month (depending on wage or salary period). These payments are registered for all individuals employed as wage earners in Denmark back to 1964. Based on this information, we are able to construct a rather precise measure of accumulated experience. The deficiency is that ATP until recently has not been paid by self-employed individuals or assisting spouses and thus, periods employed in these types of jobs do not add to the accumulated experience. Since many immigrants are self-employed, we expect to underestimate the actual working experience of immigrants.

\footnotetext{
${ }^{9}$ The 200-hour restriction is imposed because of measurement errors in employed hours for individuals with few working hours, see for instance Westergård-Nielsen (1988). These measurement errors also give rise to measurement errors in observed wage rates since the hourly wage rates are calculated as annual earnings divided by annual employed hours.

$1016 \%$ of the employed immigrants are self-employed whereas only $8 \%$ of the employed native born are selfemployed.
} 
In the estimated model, the variables representing age, experience and years since migration are allowed to affect the wage rate and employment probability non-linearly. The effect of age is represented by the variables Age and Age squared. However, we prefer to use a spline function instead of squared terms for the YSM- and EXPER variables in order to increase functional flexibility and in order to allow for the fact that in some of the groups there are relatively few observations with large values for the YSM- and EXPER variables.

A major problem for the analysis is that the registers contain no information on fluency in Danish language and the type or length of education and experience obtained before immigration to Denmark. The average length of education obtained before immigration varies considerably between native countries, see Barro and Lee (1993). Therefore, the lack of information on education obtained in the native country is expected to be a large problem. The problem is handled by using the panel data model described in Section 4, where the unobserved preimmigration educational level is treated as an individual unobserved time-constant effect. If the unobserved educational level acquired in country of origin is correlated with the included explanatory variables, this may result in inconsistently estimated coefficients in the random effect estimator which is applied. As an alternative to the random effects estimator, we could have used a fixed effects estimator, which does not suffer from this problem. However, the implication of using fixed effects is that the parameters on all time-invariant parameters are lost, including variables such as country of origin, unemployment rate in the year of immigration etc. In this study, these parameters are of primary importance. In addition, the random effects estimator is more efficient than the fixed effects estimator. Finally, the fixed effects estimator does not correct for time-varying sample selection bias. For these reasons, we have preferred the random effects estimator in this study. The random effect estimator is expected to capture time invariant unobserved heterogeneity, but we are not able to control for unobserved proficiency in speaking the Danish language which probably varies over time for the individual immigrant.

The sample contains information on the type of education acquired in Denmark. We include indicator variables for different levels of education instead of using length of education. The reason is that immigrants often start in the Danish educational system by taking courses within a year or two which give them formal qualifications corresponding to 8-9 years of compulsory schooling for Danish born individuals (the compulsory length of schooling in Denmark has been 9 years since the start of the 1970s). For the groups of immigrants the excluded category in the estimations is 'no schooling or education in Denmark' while for the group of Danish born it is 'no education or schooling beyond compulsory schooling'.

If the labour market is tight at the year of entry, it is probably considerably easier to get a job than in periods of high unemployment, and this may have long-term effects on the labour market 
career. Therefore, we include a variable indicating the overall Danish unemployment rate in the year of immigration. For Danish born individuals the analogue variable is the aggregate unemployment rate in the year the individual leaves the educational system.

Finally, a number of other socio-economic and demographic variables are included in the estimations.

\section{Estimation Results}

The results from the joint estimation of wage and employment equations are presented in Tables 3 - 4. Table 3 shows the coefficients from the employment relation where the dependent variable indicates whether the individual is employed or non-employed.

Table 3 shows large differences between the group of refugee immigrants and the group of nonrefugee immigrants and even larger differences between immigrants and the native born population with respect to the determinants of employment probabilities ${ }^{11}$.

\footnotetext{
${ }^{11}$ In estimations not shown here, we have estimated a more simple model with separate probit estimation of the probability of employment baed on the pooled sample. These estimation results are available from the authors upon request. The importance of using a panel data model which controls for unobserved time constant heterogeneity is mainly apparent for the group of non-refugee immigrants while the deviations between the pooled separate probit estimations and the random effect model are minor for refugees and Danish born individuals.
} 
Table 3. Employment relation. Coefficients from random effect model of wage and employment. Men aged 20-59 years.

Dependent variable: 1 if employed (wage earner or self-employed) and 0 else

Constant 1
Constant 2
Country of origin ${ }^{l}$ :
EU countries (12)
Turkey
Other European countries
Africa
North America
South \& Latin America
Sri Lanka, Iran \& Iraq
Vietnam
Pakistan
No citizenship
Others

Educational categories ${ }^{2}$ :

Education, primary

Education, secondary

Education, vocational

Education, theoretical 1

Education, theoretical 2

Education, theoretical 3

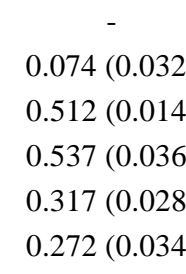

Non-Refugees

Danish

Refugees

$0.150(0.072)$

4.255 (0.125)

$1.004(0.082)$

$3.518(0.079)$

$\mathrm{YSM} / 100^{3}$

YSM (5+ years) $/ 100^{3}$

YSM (10+ years) $/ 100^{3}$

YSM (20+ years) $/ 100^{3}$

Age /100

Age, squared/10000

$-3.418(0.459)$

$2.098(0.564)$

$\mathrm{UIM}^{4}$

$$
-5.346(0.241)
$$

$-0.653(0.014)$

$0.399(0.045)$

$0.495(0.052)$

$0.555(0.029)$

$0.004(0.013)$

No. of children
$-0.045(0.018)$

$\begin{array}{cc}- & 0.322(0.013) \\ - & 0.045(0.015) \\ 0.269(0.013) & 0.111(0.016) \\ -0.377(0.027) & -0.007(0.017) \\ - & 0.060(0.021) \\ 0.430(0.023) & -0.124(0.031) \\ - & 0.101(0.078) \\ 0.286(0.013) & - \\ - & 0.129(0.018) \\ -0.363(0.012) & - \\ -0.206(0.041) & 0.038(0.017)\end{array}$

$-0.085(0.028)$

$-0.034(0.012)$

$-0.032(0.041)$

$0.342(0.021)$

$0.624(0.039)$

$0.119(0.040)$

$0.536(0.040)$

$0.077(0.039)$

$0.522(0.029)$

$0.529(0.051)$

$6.930(0.591)$

$26.992(0.595)$

$-6.983(0.919)$

$-23.237(0.926)$

-3.364 (0.607)

$-6.503(0.759)$

-0.269 (1.322)

$3.775(0.361)$

$0.570(0.399)$

-7.620 (0.466)

-4.503 (0.533)

$-5.900(0.228)$

-7.905 (0.355)

$-0.251(0.011)$

$-0.150(0.014)$

0.183 (0.019)

$-0.072(0.021)$

$0.208(0.022)$

$0.047(0.025)$

$0.257(0.017)$

0.235 (0.021)

$-0.076(0.006)$
-0.077 (0.006)

47,259

44,897

48,887

No. of observations

1. Excluded category for refugees is Sri Lanka, Iran and Iraq and excluded category for non-refugees is other Nordic countries

2. Excluded category is 'primary education' for Danish born individuals and 'no education in Denmark' for immigrants.

3. YSM is years since migration.

4. UIM is the aggregate unemployment rate in the year of entering the Danish labour market. If the unemployment rate is $10 \%$, $U I M=0.1$.

5. The log-likelihood for the joint wage and employment random effect model is shown in Table 4 . The estimated probabilities of the constant terms are also shown in Table 4. 
Within the group of refugee immigrants, immigrants from Africa and individuals from Palestine with no citizenship have significantly lower employment probabilities than all other groups. The excluded category for refugee immigrants is 'Sri Lanka, Iran and Iraq'. Refugee immigrants from 'other European countries' (Ex-Yugoslavia), South and Latin America and Vietnam tend to have significantly higher employment probabilities than refugees from Sri Lanka, Iran and Iraq. For the group of non-refugee immigrants the excluded category is 'other Nordic countries'. In general, the differences between the indicators for country of origin are much smaller for this group, compared to the refugee immigrants. Furthermore, the size and signs of these indicators do not show the same structure as for refugees, indicating that it is very important to estimate separate functions for refugees and non-refugees.

Turning to the educational indicators, Table 3 shows that having a formal education, either vocational or theoretic, improves the employment probability considerably for immigrants as well as for Danes. Again, there are some remarkable differences between refugees and non-refugees where the latter group seems to improve their employment prospects much more than refugees when having a short or medium term theoretical education.

The overall unemployment at the year of entry on the Danish labour market, UIM, has a negative long-term effect on the employment probability for both groups of immigrants and for Danish born individuals. ${ }^{12}$ The variables reflecting household conditions are included in the estimations, partly in order to capture possible labour supply effects, and partly because they work as identifying the model since the child variables are not included in the wage equation. The coefficients on these variables do not vary much between immigrants and Danish born men.

The variables reflecting years since migration $(Y S M)$ and the age variables define the assimilation process. For Danish born individuals, the employment probability decreases with age at a decreasing rate. For immigrants, especially non-refugee immigrants, the employment probability increases with age, but at a decreasing rate, ceteris paribus. The variables reflecting YSM are represented by a spline function which turns out to give strongly significant coefficients. The coefficients enter in a cumulative way. Thus, for instance refugees with 0-5 years spent in Denmark have a coefficient of 26.992, refugees with 5-10 years have the coefficient $26.992+(-$ $23.237)$, refugees with $10-20$ years have the coefficient $26.992+(-23.237)+(-6.503)$, etc. The estimations indicate that the employment probability increases during the first 5 years spend in Denmark for non-refugee immigrants and during the first 10 years for refugees, but after that time the employment probability decreases with YSM.

\footnotetext{
${ }^{12}$ In other estimations, not presented here, we tried to interact UIM with the experience and YSM (years since migration) variables in order to test for short- and long-term effects of UIM. These experiments indicated that UIM should only enter the model via the constant term since the interaction effects generally turned out to be insignificant.
} 
In order to facilitate the analysis of the assimilation process, we have calculated the predicted probabilities of being employed, based on the estimations presented in Table 3. These are calculated for a 'standard individual' who immigrated at the age of 26, is a single person without children, he is employed as a skilled worker and he has the equivalent of a vocational education from a Danish school. The similar Dane is 26 years and has been in the labour market for 7 years. The unemployment at the year of entering the labour market was 10 percent for both 'standard individuals'. The constant term for the 'standard immigrant' is a weighted average of the countries of origin. ${ }^{13}$

Figure 2. Predicted employment probabilities for refugees, 'non-refugees', and Danish born men.

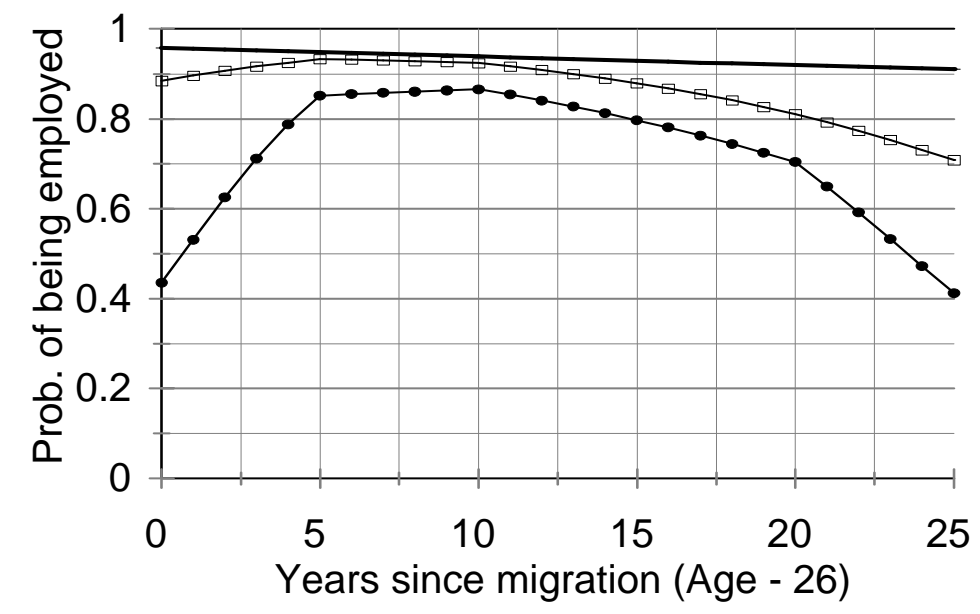

$\rightarrow$ Refugees $\quad \rightarrow$ Non-Refugees — Danish born

Source: see text.

Figure 2 illustrates a clear employment assimilation profile for the first 10 years spent in Denmark. Both immigrant groups start with lower employment probabilities than Danish born men when entering the Danish labour market. When migrating to Denmark, non-refugees (labour migrants and tied movers) have much higher employment probabilities than refugees, about 90 percent compared to about 40 percent for refugees and about 95 percent for Danish born men. After 10 years, the employment rates are rather close for all three groups, partly because the employment rate decreases for Danes, but mainly because immigrants seem to assimilate with respect to employment probabilities. For immigrants who have spent more than 20 years in Denmark the employment situation seems to worsen, especially for refugees. However, this part

\footnotetext{
${ }^{13}$ Further, the two constant terms - from the random effects specification - are weighted with their relative probabilities shown in Table 4.
} 
of the curves is based on estimated coefficients with a fairly high standard error, see Table 3 , since relatively few refugees have spent more than 10 years in Denmark.

The second part of the estimations from the joint employment and wage model is shown in Table 4 which shows the estimation of wage functions for the 'Classical Model' and the 'Employment Model' ${ }^{14}$ Comparing the estimated 'Classical Model' for immigrants and natives, there is a clear difference with respect to the coefficients reflecting returns to human capital and occupational attainment. Most of the coefficients are lower or more negative for both immigrant groups compared to Danes. For instance the coefficients to educational and occupational variables are much lower for immigrants than for Danes. ${ }^{15}$ Somewhat surprisingly, the constant terms for immigrants are larger than for Danes, indicating that for the excluded category of immigrants (refugees from Sri Lanka, Iran \& Iraq and non-refugees from the Nordic countries) working as unskilled workers (the excluded occupational category) the wage rates tend to be higher than for Danes, ceteris paribus

Looking at the indicators for country of origin, the sign and size of the coefficients show a different structure compared to the employment model. As an example, the coefficient to the indicator for 'non-refugees' from EU-countries is significantly positive in the employment relation, but it is significantly negative in the wage relation. Refugees from Africa have lower chances of getting a job but if they succeed, they tend to get about the same wages as other refugees (or more precisely, the comparison group from Sri Lanka, Iran \& Iraq). Exactly the opposite story holds for Vietnamese refugees and immigrants from Pakistan who have high employment chances, but tend to have low wages.

Comparing the results for immigrants and Danes for the 'Classical Model', we may get an idea about the earnings assimilation process going on for immigrants in the Danish labour market. Ignoring the squared terms, the coefficient to the age variable of Danish born individuals is much larger than for refugee immigrants while the difference to non-refugee immigrants is smaller. Adding the effect from the spline variables representing years since migration (YSM) does not change the picture much since the negative coefficient to the general effect of YSM almost cancels the positive coefficients for individuals who spend more than 5 years in Denmark.

\footnotetext{
${ }^{14}$ In the Appendix C, Table C1, different econometric specifications are compared and discussed for the two groups of immigrants in order to evaluate the importance of selection processes, unobserved heterogeneity and possible cohort effects due to changes in the composition of immigrants.

${ }^{15}$ It should be kept in mind that the reference group differs for Danes and immigrants. For Danes the reference group is those with primary education, for immigrants the reference group is no education in Denmark.
} 
Table 4. Hourly wage relation. Coefficients from random effect model of joint wage and employment. Men aged 20-59 years. Dependent variable log hourly wage rate in DKK 1995prices.

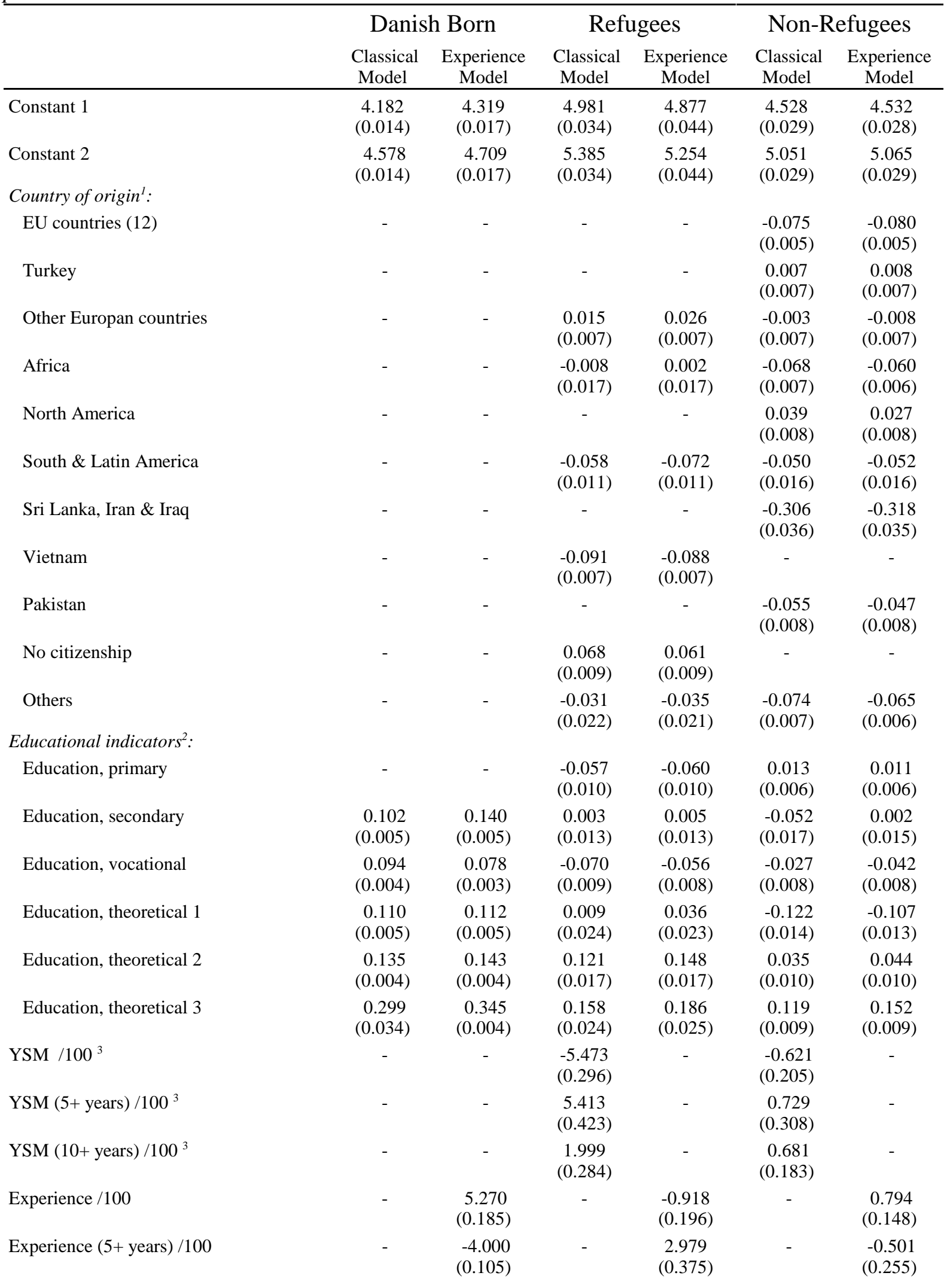




\begin{tabular}{|c|c|c|c|c|c|c|}
\hline Experience $(10+$ years $) / 100$ & - & $\begin{array}{l}-0.315 \\
(0.105)\end{array}$ & - & $\begin{array}{l}-1.845 \\
(0.361)\end{array}$ & - & $\begin{array}{c}0.736 \\
(0.197)\end{array}$ \\
\hline Non-experience /100 & - & - & - & $\begin{array}{l}-1.919 \\
(0.178)\end{array}$ & - & $\begin{array}{r}-0.580 \\
(0.097)\end{array}$ \\
\hline Non-experience $(5+$ years $) / 100$ & - & - & - & $\begin{array}{c}1.650 \\
(0.351)\end{array}$ & - & $\begin{array}{c}0.632 \\
(0.222)\end{array}$ \\
\hline Non-experience $(10+$ years $) / 100$ & - & - & - & $\begin{array}{c}1.019 \\
(0.577)\end{array}$ & - & $\begin{array}{c}0.914 \\
(0.298)\end{array}$ \\
\hline Age/100 & $\begin{array}{c}2.685 \\
(0.069)\end{array}$ & $\begin{array}{c}0.682 \\
(0.083)\end{array}$ & $\begin{array}{c}0.546 \\
(0.148)\end{array}$ & $\begin{array}{c}0.404 \\
(0.223)\end{array}$ & $\begin{array}{c}1.572 \\
(0.139)\end{array}$ & $\begin{array}{c}1.429 \\
(0.141)\end{array}$ \\
\hline Age, squared/10000 & $\begin{array}{l}-2.901 \\
(0.087)\end{array}$ & $\begin{array}{l}-1.161 \\
(0.100)\end{array}$ & $\begin{array}{l}-0.100 \\
(0.198)\end{array}$ & $\begin{array}{c}-0.042 \\
(0.295)\end{array}$ & $\begin{array}{l}-1.150 \\
(0.177)\end{array}$ & $\begin{array}{l}-1.115 \\
(0.180)\end{array}$ \\
\hline $\mathrm{UIM}^{4}$ & $\begin{array}{c}0.809 \\
(0.044)\end{array}$ & $\begin{array}{c}0.563 \\
(0.044)\end{array}$ & $\begin{array}{c}0.998 \\
(0.170)\end{array}$ & $\begin{array}{c}0.505 \\
(0.159)\end{array}$ & $\begin{array}{c}1.101 \\
(0.084)\end{array}$ & $\begin{array}{c}1.120 \\
(0.076)\end{array}$ \\
\hline Single & $\begin{array}{r}-0.037 \\
(0.002)\end{array}$ & $\begin{array}{r}-0.031 \\
(0.002)\end{array}$ & $\begin{array}{c}0.010 \\
(0.006)\end{array}$ & $\begin{array}{c}0.018 \\
(0.006)\end{array}$ & $\begin{array}{c}0.002 \\
(0.004)\end{array}$ & $\begin{array}{c}0.004 \\
(0.004)\end{array}$ \\
\hline \multicolumn{7}{|l|}{ Occupational category $^{5}$ : } \\
\hline Manager and high level salaried worker & $\begin{array}{c}0.130 \\
(0.003)\end{array}$ & $\begin{array}{c}0.121 \\
(0.003)\end{array}$ & $\begin{array}{c}0.034 \\
(0.008)\end{array}$ & $\begin{array}{c}0.038 \\
(0.008)\end{array}$ & $\begin{array}{c}0.088 \\
(0.005)\end{array}$ & $\begin{array}{c}0.077 \\
(0.005)\end{array}$ \\
\hline Salaried worker, low level & $\begin{array}{r}-0.014 \\
(0.003)\end{array}$ & $\begin{array}{r}-0.026 \\
(0.003)\end{array}$ & $\begin{array}{l}-0.054 \\
(0.009)\end{array}$ & $\begin{array}{l}-0.053 \\
(0.009)\end{array}$ & $\begin{array}{r}-0.016 \\
(0.006)\end{array}$ & $\begin{array}{r}-0.017 \\
(0.005)\end{array}$ \\
\hline Skilled & $\begin{array}{c}0.045 \\
(0.003)\end{array}$ & $\begin{array}{c}0.040 \\
(0.003)\end{array}$ & $\begin{array}{c}0.052 \\
(0.008)\end{array}$ & $\begin{array}{c}0.051 \\
(0.008)\end{array}$ & $\begin{array}{c}0.012 \\
(0.006)\end{array}$ & $\begin{array}{c}0.011 \\
(0.006)\end{array}$ \\
\hline Missing occupation & $\begin{array}{r}-0.105 \\
(0.004) \\
\end{array}$ & $\begin{array}{r}-0.074 \\
(0.004) \\
\end{array}$ & $\begin{array}{l}-0.105 \\
(0.006) \\
\end{array}$ & $\begin{array}{r}-0.089 \\
(0.006) \\
\end{array}$ & $\begin{array}{r}-0.098 \\
(0.005) \\
\end{array}$ & $\begin{array}{r}-0.091 \\
(0.005) \\
\end{array}$ \\
\hline variance of $\varepsilon^{6}$ & $\begin{array}{c}0.262 \\
(0.0002)\end{array}$ & $\begin{array}{c}0.258 \\
(0.0002)\end{array}$ & $\begin{array}{c}0.382 \\
(0.0010)\end{array}$ & $\begin{array}{c}0.369 \\
(0.0009)\end{array}$ & $\begin{array}{c}0.381 \\
(0.0007)\end{array}$ & $\begin{array}{c}0.379 \\
(0.0007)\end{array}$ \\
\hline Correlation of $\varepsilon$ and $v^{6}$ & $\begin{array}{c}-0.151 \\
(0.0216)\end{array}$ & $\begin{array}{c}-0.020 \\
(0.0257)\end{array}$ & $\begin{array}{c}-0.926 \\
(0.0023)\end{array}$ & $\begin{array}{c}-0.905 \\
(0.0029)\end{array}$ & $\begin{array}{c}-0.897 \\
(0.0022)\end{array}$ & $\begin{array}{c}-0.891 \\
(0.0023)\end{array}$ \\
\hline $\mathrm{P} 1^{6}$ & $\begin{array}{c}0.365 \\
(0.0116)\end{array}$ & $\begin{array}{c}0.328 \\
(0.0116)\end{array}$ & $\begin{array}{c}0.828 \\
(0.0082)\end{array}$ & $\begin{array}{c}0.795 \\
(0.0096)\end{array}$ & $\begin{array}{c}0.737 \\
(0.0076)\end{array}$ & $\begin{array}{c}0.741 \\
(0.0076)\end{array}$ \\
\hline $\mathrm{P} 2^{6}$ & $\begin{array}{c}0.151 \\
(0.0081)\end{array}$ & $\begin{array}{c}0.191 \\
(0.0087)\end{array}$ & $\begin{array}{c}0.093 \\
(0.0078)\end{array}$ & $\begin{array}{c}0.121 \\
(0.0095)\end{array}$ & $\begin{array}{c}0.089 \\
(0.0060)\end{array}$ & $\begin{array}{c}0.088 \\
(0.0060)\end{array}$ \\
\hline $\mathrm{P} 3^{6}$ & $\begin{array}{c}0.410 \\
(0.0104)\end{array}$ & $\begin{array}{c}0.418 \\
(0.0103)\end{array}$ & $\begin{array}{c}0.069 \\
(0.0043)\end{array}$ & $\begin{array}{c}0.072 \\
(0.0045)\end{array}$ & $\begin{array}{c}0.130 \\
(0.0057)\end{array}$ & $\begin{array}{c}0.129 \\
(0.0057)\end{array}$ \\
\hline $\mathrm{P} 4^{6}$ & $\begin{array}{c}0.074 \\
(0.0050) \\
\end{array}$ & $\begin{array}{c}0.064 \\
(0.0049) \\
\end{array}$ & $\begin{array}{c}0.011 \\
(0.0017) \\
\end{array}$ & $\begin{array}{c}0.013 \\
(0.0019) \\
\end{array}$ & $\begin{array}{c}0.045 \\
(0.0033) \\
\end{array}$ & $\begin{array}{c}0.042 \\
(0.0032) \\
\end{array}$ \\
\hline $\begin{array}{l}\text { Number of observations with an observed } \\
\text { hourly wage rate }\end{array}$ & 34,453 & 34,453 & 12,724 & 12,724 & 25,380 & 25,830 \\
\hline $\begin{array}{l}\text { Number of observations in employment } \\
\text { relation }\end{array}$ & 47,529 & 47,529 & 44,897 & 44,897 & 48,887 & 48,887 \\
\hline Mean log likelihood ${ }^{6}$ & -0.360 & -0.351 & -0.615 & -0.617 & -0.716 & -0.715 \\
\hline
\end{tabular}

1. Excluded category for refugees is Sri Lanka, Iran and Iraq and for non-refugees it is other Nordic countries.

2. Excluded category is 'primary education' for Danish born individuals and 'no education in Denmark' for immigrants.

3. $Y S M$ is years since migration.

4. UIM is unemployment in the year of entering the Danish labour market. UIM assumes values in the interval $[0,1]$.

5. Excluded category is 'unskilled worker'.

6. Refers to the estimates of the joint wage and employment random effect model. If D1, D2, C1, and C2 denote the constant terms in the employment and wage functions, respectively, then $\mathrm{P} 1$ is the joint probability of $\mathrm{D} 1$ and $\mathrm{C} 1, \mathrm{P} 2$ is the joint probability of D1 and C2, P3 is the joint probability of D2 and C1, and P4 is the joint probability of D2 and C2.

Figure 3 summarises the estimated wage profile for 'standard' individuals as described for Figure 2. It should be clear that the predictions have higher standard errors the higher values of YSM, mainly for refugees because there are few refugees in the sample who have spent more than 10 
years in Denmark. The figure shows that for a 'standard' non-refugee immigrant, the starting wage level is very close to the level for a Danish worker, and the wage growth for a non-refugee is slightly larger than for a Danish born worker. ${ }^{16}$ For refugees the profile looks less impressing. Refugees start at a significantly lower hourly wage rate. During the first years after migration, there is a higher wage growth than for Danes, but after 5 years the wage growth of refugee immigrants is only slightly higher than the wage growth of Danes, and thus, the speed of the wage assimilation process is relatively slow.

Figure 3. Predicted log hourly wage rates for refugees, non-refugees, and Danish born men. Assimilation profile estimated by 'Classical Model'.

口

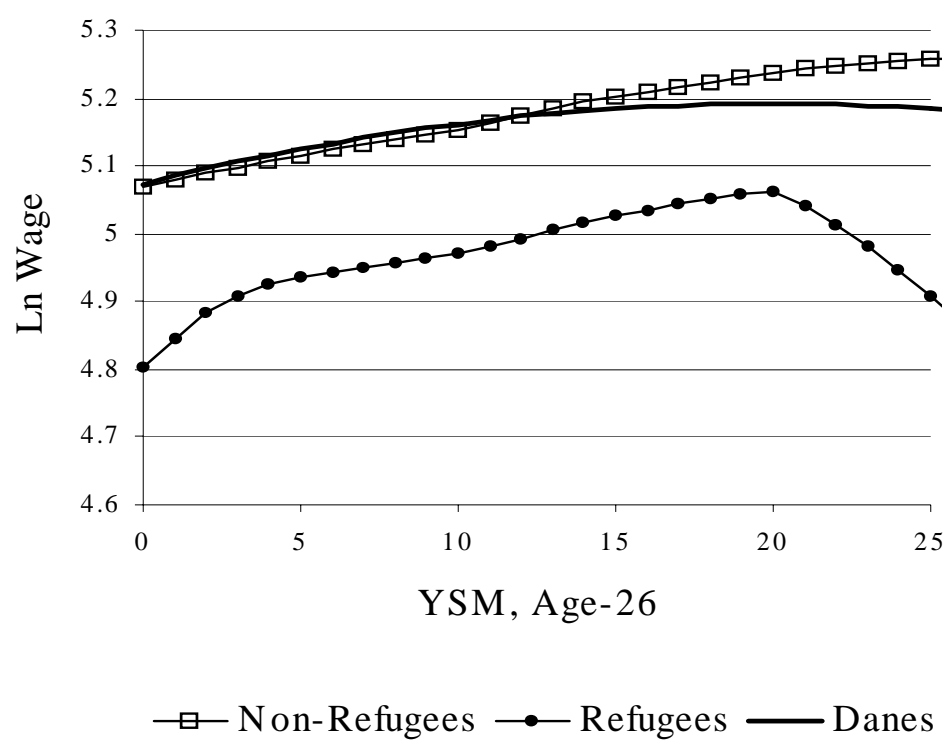

Source: See text.

One explanation of the poor performance of refugees in Figure 3 might be their weak attachment to the Danish labour market, as shown in Figure 2. If the refugees experience much higher unemployment rates than Danes, they may have difficulties in acquiring country specific human capital and increase their earnings capacity. As a preferred alternative to the 'Classical Model', we test the 'Experience Model' in Columns 2, 4 and 6 of Table 4 by splitting the number of years spent in Denmark up into time spent as employed and time spent as non-employed. As expected, the estimations for the Danish men show that the coefficient to the first 5 years of employment is positive and fairly large ( 5 percent). The corresponding coefficient is positive, but smaller, for non-refugees ( 0.8 percent) and for refugees it is even negative ( -0.9 percent). The effect turns

\footnotetext{
${ }^{16}$ The level of the curves - and hence the differences between their level - is partly determined by the choice of 'standard' person.
} 
positive for refugees after 5 years of experience, and they seem to improve their situation after 5-10 years of employment. For time spent as non-employed, there is a significantly negative effect during the first 5 years spent as non-employed, and after 5 years of non-employment the negative effect declines for refugees and disappears for non-refugees.

Figure 4. Predicted log hourly wage rates for refugees, non-refugees, and Danish born men. Assimilation profile estimated by 'Employment Model'.

\section{Full-Time Employed}

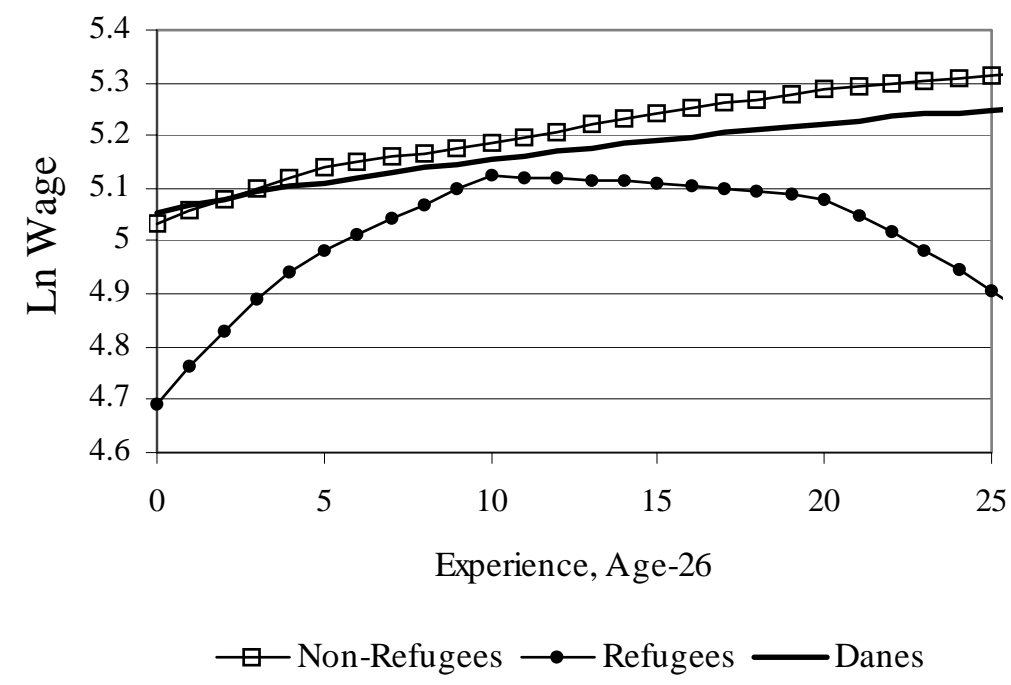

Full-Time Non-Employed

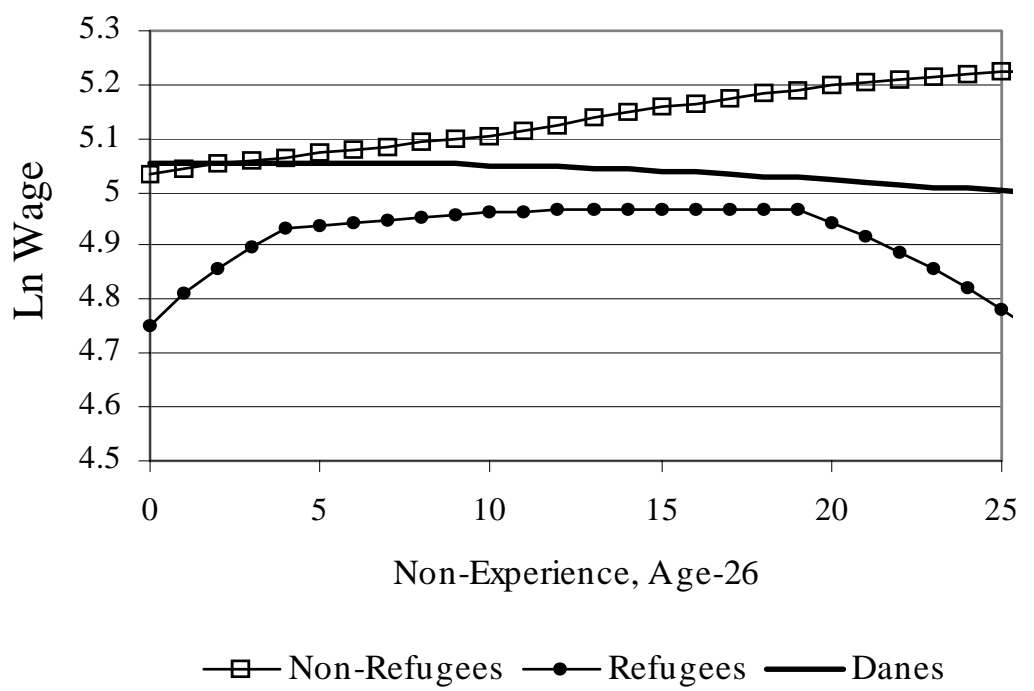

Source: See text. 
Figure 4 summarizes the results from the 'Experience Model' with respect to wage profiles during the labour market career. Ignoring the constant terms, which partly reflects the choice of 'standard' person, the profiles reflect the coefficients to age, age squared and the spline functions for time spent as employed (upper part) and the spline function for time spent as non-employed (lower part). ${ }^{17}$ The upper part shows that the hourly wage rate rises faster for full-time employed immigrants than for Danes. For refugees there is a clear indication of wage assimilation during the first 10 years spent in Denmark, conditionally on being full-time employed. For non-refugees the assimilation process is weaker, but still existing.

The lower part of Figure 4 shows the profiles of the earnings potential for Danes and immigrants if the individuals spend all their time in non-employment, either as unemployed or out of the labour market. For Danish workers this highly improbable 'employment career' would mean a constant decrease of earnings capacity, indicated by the negative slope of the curve for Danes. For refugee immigrants the first 5 years spent as unemployed do not seem to harm the assimilation process much. This evidence probably reflects the fact that virtually all refugee immigrants to Denmark spend some years in the Danish school system and most of them participate in different labour market programmes where they are most often registered as nonemployed before they enter the labour market. After the first 5 years spent as non-employed, the wage curve for refugees becomes fairly flat. For non-refugee immigrants, the non-employment wage curve is a bit surprising since it has a constantly positive slope during the whole range of years spent in non-employment. Comparing the wage growth for non-refugee immigrants in the upper and lower parts of Figure 4, the figures show that wage growth is slower for non-refugees who spend all their time as non-employed compared to non-refugees who are full-time employed. But the difference between the two wage profiles is surprisingly small. Comparing the corresponding wage profiles for Danes, non-refugee immigrants seem to much less 'punished' by unemployment with respect to earnings capacity than their Danish colleagues and refugee immigrants.

\section{Conclusion}

The analysis in this paper focuses on employment and wage assimilation of male immigrants in the Danish labour market. Based on two data sets originating from administrative registers covering each of the years 1984-1995, we estimate a random effects model of employment probabilities and hourly wage rates. The model jointly corrects for selectivity effects due to missing wages for non-participants and self-employed individuals. The panel structure of the data allows us to handle time constant unobserved heterogeneity and cohort effects due to changes in the composition of immigrants.

\footnotetext{
${ }^{17}$ The shapes of the profiles in all the Figures shown are also strongly affected by the expected value of the error terms, conditional on working, the calculation of which is shown in Appendix B.
} 
The first hypothesis that is tested concerns the different assimilation patterns of refugee and nonrefugee immigrants. The results show that there is evidence of an assimilation process for both groups in the sense that the probability of being employed increases strongly with the number of years spent in Denmark. Controlling for a number of background factors, including the number of years spent in Denmark, the initial employment probability of refugee immigrants is much lower than that of non-refugee immigrants. After 5-10 years in Denmark, the employment probability of refugees seem to approach the level of non-refugee immigrants and Danish born individuals. However, there are large differences in the initial probability of employment within the group of refugee immigrants. Refugees from Africa and Palestine have very low initial employment chances compared to refugees from Europe, Vietnam and South and Latin- America. For non-refugee immigrants the assimilation process is weaker. Non-refugee immigrants, especially immigrants from Europe and Pakistan, enter the Danish labour market with considerably higher chances of getting a job than refugee immigrants, and thus, the employment chances approaches the Danish level at a slower rate, compared to refugees.

The second hypothesis which is tested is that wage assimilation is closely related to labour market attachment. This hypothesis is confirmed for refugee immigrants as well as non-refugee immigrants, but labour market attachment is much more important for the wages of refugees than for the wages of non-refugees. On average, refugees start at much lower levels than non-refugees and Danish born workers, but there are significant differences within the groups of refugees and non-refugees. If the refugees were able to get a firm attachment to the labour market when they entered the Danish labour market, i.e. have full-time employment during their first 10 years in Denmark, their wage rates would approach the wage level of Danish workers. However, the average employment rates for different groups of refugees in Denmark indicate that very few refugees succeed in getting a firm a attachment to the Danish labour market during their first years of stay in Denmark.

\section{References}

Barro, R. J. and J.-W. Lee (1993), International Comparisons of Educational Attainment, NBER Working Paper No. 4349.

Borjas, G.J. (1987), Self-Selection and the Earnings of Immigrants, The American Economic Review 77, no. 4 , pp.531-53.

Borjas, G.J. (1994), The Economics of Immigration, Journal of Economic Literature XXXII, pp. 16671717.

Borjas, G. J. (1999), Immigration and Welfare Magnets, Journal of Labor Economics, vol. 17, no. 4, pp.607-637.

Chiswick, R.B. (1978), The Effect of Americanization on the Earnings of Foreign-Born Men, Journal of Political Economy 86, no. 5, pp. 81-87. 
Chiswick, R. B. (1999), Immigration policy and immigration quality. Are immigrants favorably selfselected?, American Economic Review, Vol. 89, no. 2, pp.181-85.

Chiswick, B.R., Y. Cohen and T. Zach (1997), The Labor Market Status of Immigrants: Effects of the Unemployment Rate at Arrival and Duration of Residence, Industrial and Labor Relations Review 50, no.2, pp. 289-303.

Chiswick, R. B. and M. E. Hurst (1999), The Employment, Unemployment and Unemployment Compensation Benefits of Immigrants, Research in Employment Policy, vol. 2, 1999, forthcoming.

Chiswick, B.R. and P.W. Miller (1995), The endogeneity between language and earnings: International analyses, Journal of Labor Economics 13, no. 2, pp. 246-88.

Chiswick, B.R. and P.W. Miller (1999), Immigrant Earnings: Language Skills, Linguistic Concentrations, and the Business Cycle, mimeo, University of Chicago: June.

Dustmann, C. (1994), Speaking fluency, writing fluency and earnings of immigrants, Journal of Population economics 7, pp. 133-156.

Dustmann, C. (1999), Temporary Migration, Human Capital and Language Fluency of Migrants, Scandinavian Journal of Economics 101, no. 2, pp. 297-314.

Dustmann, C. and A. van Soest (1998), Language and the earnings of immigrants, mimeo, University College London: September.

Hausman, J.A. and D.A. Wise (1979), Attrition bias in Experimental and Panel Data: The Gary Income Maintenance Experiment, Econometrica 47, pp. 455-473.

Heckman, J.J. (1979), Sample selection bias as a specification error, Econometrica 47, pp. 153-162.

Hummelgaard, H., L. Husted, A. Holm, M. Baadsgaard and B. Olrik (1995), Ethnic Minorities Integration and Mobility, (In Danish), AKF Forlaget, Copenhagen.

Husted, L., H. S. Nielsen, M. Rosholm, and N. Smith (1999), Double Discrimination of Immigrant Females in Denmark, Mimeo, CIM.

Kyriazidou, E. (1997), Estimation of a Panel Data Sample Selection Model, Econometrica, Vol. 65, No. 6, pp. 1335-1364.

Lalonde, R.J. and R.H. Topel (1997), The Economic Impact of International Migration and the Economic Performance of Migrants, Ch. 14 in M. R. Rosenzweig and O. Stark (eds.), Handbook in Population and Family Economics, Elsevier Science B. V.

Le Grand, C. and R. Szulkin (1999), Indvandrarnas löner i Sverige, Arbetsmarknad \& Arbetsliv 5, nr. 2, pp. 89-110.

Ministry of Economics (1997), Economic Survey, December (In Danish), Copenhagen.

Nijman, T. and M. Verbeek (1996), Incomplete Panels and Selection Bias, in Mátyás and Sevestre (eds.), The Econometrics of Panel Data, Klüwer Academic Publishers. 
OECD (1996), Employment Outlook, Paris.

Pedersen, P.J. (1996), Aggregate Intra-Nordic and Nordic-EC Mobility, in E. Wadensjö (ed.), The Nordic Labour Markets in the 1990s, Part II, North Holland.

Ridder, G. (1990), Attrition in Multi-Wave Panel Data, in Hartog, Ridder and Theeuwes (eds.), Panel Data and Labor Market Studies, Elsevier Science Publishers B.V.

Schröder, L. (1996), Scandinavian Skill Migration in the 1980s, in E. Wadensjö (ed.), The Nordic Labour Markets in the 1990s, Part II, North Holland.

Statistics Denmark (1998), Indvandrere i Danmark, Copenhagen.

Vella, F. (1998), Estimating Models with Sample Selection Bias: A Survey, The Journal of Human Resources, Vol. 33, No. 1, pp. 127-169.

Vella, F. and M. Verbeek (1994), Two-step estimation of Simultaneous Equation Panel Data Models with Censored Endogenous Variables, CentER Discussion Paper 9455, Tilburg.

Verbeek, M. and T. Nijman (1992), Testing for Selectivity Bias in Panel Data Models, International Economic Review, Vol. 33, No. 3, pp. 681-703.

Westergård-Nielsen, N. (1984), Description of a Danish longitudinal data base, Working Paper 84-1, Aarhus School of Business. 


\section{Appendix}

Table A1. Mean sample values. First generation male immigrants and Danish born males. 19841995.

\begin{tabular}{|c|c|c|c|c|c|c|}
\hline & \multicolumn{2}{|c|}{ Danish born } & \multicolumn{2}{|c|}{ Refugees } & \multicolumn{2}{|c|}{ Non-refugees } \\
\hline & Mean & Std. dev. & Mean & Std. dev. & Mean & Std. dev. \\
\hline Log Wage & 5.00 & 0.35 & 4.81 & 0.37 & 4.94 & 0.42 \\
\hline Employment rate & 0.89 & 0.31 & 0.43 & 0.49 & 0.71 & 0.45 \\
\hline Nordic countries & - & - & - & - & 0.12 & 0.32 \\
\hline EU countries (12) & - & - & - & - & 0.29 & 0.45 \\
\hline Turkey & - & - & - & - & 0.19 & 0.40 \\
\hline Other European countries & - & - & 0.13 & 0.33 & 0.10 & 0.30 \\
\hline Africa & - & - & 0.05 & 0.21 & 0.09 & 0.29 \\
\hline North America & - & - & - & - & 0.04 & 0.20 \\
\hline South \& Latin America & - & - & 0.03 & 0.16 & 0.02 & 0.13 \\
\hline Sri Lanka, Iran, Iraq & - & - & 0.46 & 0.50 & 0.00 & 0.05 \\
\hline Vietnam & - & - & 0.15 & 0.36 & - & - \\
\hline Pakistan & - & - & - & - & 0.07 & 0.26 \\
\hline No citizenship & - & - & 0.19 & 0.39 & - & - \\
\hline Others & - & - & 0.01 & 0.11 & 0.08 & 0.28 \\
\hline Education, none (excl. categ) & - & - & 0.80 & 0.40 & 0.77 & 0.43 \\
\hline Education, primary & 0.32 & 0.46 & 0.06 & 0.23 & 0.12 & 0.32 \\
\hline Education, secondary & 0.03 & 0.16 & 0.02 & 0.14 & 0.01 & 0.11 \\
\hline Education, vocational & 0.47 & 0.50 & 0.08 & 0.27 & 0.04 & 0.20 \\
\hline Education, theoretical 1 & 0.05 & 0.22 & 0.01 & 0.12 & 0.01 & 0.12 \\
\hline Education, theoretical 2 & 0.07 & 0.25 & 0.02 & 0.13 & 0.02 & 0.14 \\
\hline Education, theoretical 3 & 0.06 & 0.23 & 0.01 & 0.10 & 0.03 & 0.16 \\
\hline Age $/ 100$ & 0.39 & 0.11 & 0.32 & 0.08 & 0.35 & 0.09 \\
\hline Age, squared /10000 & 0.16 & 0.09 & 0.11 & 0.06 & 0.13 & 0.07 \\
\hline YSM /100 & - & - & 0.06 & 0.04 & 0.09 & 0.06 \\
\hline YSM 5+ years /100 & - & - & 0.02 & 0.04 & 0.05 & 0.05 \\
\hline YSM $10+$ years $/ 100$ & - & - & 0.01 & 0.02 & 0.02 & 0.04 \\
\hline Experience /100 & 0.13 & 0.08 & 0.02 & 0.03 & 0.05 & 0.05 \\
\hline Experience $5+$ years $/ 100$ & 0.09 & 0.08 & 0.00 & 0.02 & 0.02 & 0.04 \\
\hline Experience $10+$ years $/ 100$ & 0.05 & 0.06 & 0.00 & 0.01 & 0.01 & 0.02 \\
\hline Non-experience $/ 100$ & - & - & 0.04 & 0.03 & 0.04 & 0.04 \\
\hline Non-exper. $5+$ years $/ 100$ & - & - & 0.01 & 0.02 & 0.02 & 0.03 \\
\hline Non-exper. $10+$ years $/ 100$ & - & - & 0.00 & 0.01 & 0.00 & 0.02 \\
\hline UIM & 0.04 & 0.03 & 0.08 & 0.02 & 0.07 & 0.03 \\
\hline Single & 0.31 & 0.46 & 0.50 & 0.50 & 0.33 & 0.47 \\
\hline Youngest child 0-2 & 0.10 & 0.30 & 0.21 & 0.40 & 0.21 & 0.41 \\
\hline Youngest child 3-6 & 0.08 & 0.28 & 0.11 & 0.31 & 0.13 & 0.33 \\
\hline Youngest child 7-17 & 0.22 & 0.41 & 0.11 & 0.31 & 0.15 & 0.35 \\
\hline No. of children & 0.68 & 0.95 & 0.91 & 1.35 & 0.94 & 1.20 \\
\hline $\begin{array}{l}\text { Manager and high level } \\
\text { salaried worker }\end{array}$ & 0.23 & 0.42 & 0.05 & 0.22 & 0.12 & 0.32 \\
\hline Salaried worker, low level & 0.13 & 0.33 & 0.03 & 0.17 & 0.06 & 0.24 \\
\hline Skilled & 0.19 & 0.39 & 0.04 & 0.20 & 0.06 & 0.25 \\
\hline Unskilled (Excl. category) & 0.27 & 0.16 & 0.17 & 0.38 & 0.31 & 0.45 \\
\hline Missing occupation & 0.18 & 0.38 & 0.71 & 0.45 & 0.45 & 0.50 \\
\hline Number of observations & \multicolumn{2}{|c|}{47259} & \multicolumn{2}{|c|}{44897} & \multicolumn{2}{|c|}{48887} \\
\hline
\end{tabular}




\section{Appendix B. The Likelihood function and Calculation of Expected Errors in the Wage Equation.}

The likelihood of a single observation for the model specified in section 4, conditional on the random effects, is,

$$
\begin{aligned}
& L_{i t}\left(\psi ; \alpha_{i}, \eta_{i}\right)=f\left(\varepsilon_{i t}, v_{i t} \mid \alpha_{i}, \eta_{i}\right) \\
& =\left[\int_{-z_{i j} \gamma-\eta_{i}}^{\infty} \phi_{\varepsilon v}\left(y_{i t}-x_{i t} \beta-\alpha_{i}, v_{i t}\right) d v\right]^{d_{i t} \cdot c_{i t}} \\
& \times\left[\int_{-z_{i t} \gamma-\eta_{i}}^{\infty} \phi_{v}(v) d v\right]^{d_{i i} \cdot\left(1-c_{i t}\right)} \times\left[\int_{-\infty}^{-z_{u} \gamma-\eta_{i} \infty} \int_{-\infty}^{\infty} \phi_{\varepsilon v}\left(\varepsilon_{i t}, v_{i t}\right) d \varepsilon d v\right]^{1-d_{i t}} \\
& =\left[\int_{-z_{i y} \gamma-\eta_{i}}^{\infty} \phi_{v \mid \varepsilon}\left(v_{i t} \mid y_{i t}-x_{i t} \beta-\alpha_{i}\right) \cdot \phi_{\varepsilon}\left(y_{i t}-x_{i t} \beta-\alpha_{i}\right) d v\right]^{d_{i t} \cdot c_{i t}} \\
& \times\left[\int_{-z_{u} \gamma-\eta_{i}}^{\infty} \phi_{v}(v) d v\right]^{d_{d_{i i}} \cdot\left(1-c_{i n}\right)} \times\left[\int_{-\infty}^{-z_{u} \gamma-\eta_{i}} \phi_{v}(v) d v\right]^{1-d_{u t}} \\
& =\left[\left(1-\Phi_{v \mid \varepsilon}\left(-z_{i t} \gamma-\eta_{i} \mid y_{i t}-x_{i t} \beta-\alpha_{i}\right)\right) \cdot \phi_{\varepsilon}\left(y_{i t}-x_{i t} \beta-\alpha_{i}\right)\right]^{d_{i t} \cdot c_{i t}} \\
& \times\left[\Phi_{v}\left(z_{i t} \gamma+\eta_{i}\right)\right]^{d_{i t} \cdot\left(1-c_{i t}\right)} \times\left[\Phi_{v}\left(-z_{i t} \gamma-\eta_{i}\right)\right]^{1-d_{i t}}
\end{aligned}
$$

where the conditional distribution is as follows

$$
v \mid \varepsilon \sim \quad N\left(\frac{\rho \varepsilon}{\sigma_{\varepsilon}},\left(1-\rho^{2}\right)\right)
$$

It is now straightforward to specify a distribution for the random effects and integrate them out of the likelihood function. Let the number of observations on individual $i$ be $T_{i}$. Suppose that $(\alpha, \eta)$ is distributed according to $G($.$) . We then have$

$$
L_{i}(\psi)=\int_{-\infty-\infty}^{\infty} \int^{\infty}\left[\prod_{t=1}^{T_{i}} f\left(\varepsilon_{i t}, v_{i t} \mid \alpha_{i}, \eta_{i}\right)\right] \cdot g\left(\alpha_{i}, \eta_{i}\right) d \alpha_{i} d \eta_{i}
$$

This is the likelihood function used for estimation in this paper. The function G(.) is assumed to be a bivariate discrete distribution with $2 \times 2$ points of support. The parameters of the mixing distribution are identified non-parametrically up to a normalisation, due to the panel structure of data. 
When drawing wage assimilation profiles, we need to calculate the expected wage, given that an individual works, that is, we must calculate

$$
E\left[w_{i t} \mid z_{i t} \gamma+\eta_{i}+v_{i t}>0\right]=x_{i t} \beta+E\left[\alpha_{i}+\varepsilon_{i t} \mid z_{i t} \gamma+\eta_{i}+v_{i t}>0\right]
$$

$\mathrm{S}$ the error terms in the selection equation and the wage equation are correlated, the second term on the right hand side above is generally non-zero. To calculate this expectation, first note that, by orthogonality of idiosyncratic errors and random effects,

$$
\begin{aligned}
E\left[\alpha_{i}+\varepsilon_{i t} \mid z_{i t} \gamma+\eta_{i}+v_{i t}>0\right] & =E\left[\alpha_{i} \mid z_{i t} \gamma+\eta_{i}+v_{i t}>0\right] \\
& +E\left[\varepsilon_{i t} \mid z_{i t} \gamma+\eta_{i}+v_{i t}>0\right]
\end{aligned}
$$

Let us look at the second term first. It may be expressed in the following way, exploiting the distributional assumptions made explicit in the paper

$$
\begin{aligned}
E\left[\varepsilon_{i t} \mid z_{i t} \gamma+\eta_{i}+v_{i t}>0\right] & =\operatorname{Pr}\left(\eta_{1}\right) \cdot \sigma_{\varepsilon} \cdot \rho_{\varepsilon v} \cdot \frac{\phi\left(z_{i t} \gamma+\eta_{1}\right)}{\Phi\left(z_{i t} \gamma+\eta_{1}\right)} \\
& +\operatorname{Pr}\left(\eta_{2}\right) \cdot \sigma_{\varepsilon} \cdot \rho_{\varepsilon v} \cdot \frac{\phi\left(z_{i t} \gamma+\eta_{2}\right)}{\Phi\left(z_{i t} \gamma+\eta_{2}\right)}
\end{aligned}
$$

The first term is slightly more complicated, but may be calculated in the following way

$$
\begin{aligned}
E\left[\alpha_{i} \mid z_{i t} \gamma+\eta_{i}+v_{i t}>0\right] & =\int \alpha_{i} \cdot f\left(\alpha_{i} \mid z_{i t} \gamma+\eta_{i}+v_{i t}>0\right) d \alpha_{i} \\
& =\int \alpha_{i} \cdot \frac{f\left(\alpha_{i}, z_{i t} \gamma+\eta_{i}+v_{i t}>0\right)}{\operatorname{Pr}\left(z_{i t} \gamma+\eta_{i}+v_{i t}>0\right)} d \alpha_{i} \\
& =\int \alpha_{i} \cdot \frac{f\left(\alpha_{i}\right) \cdot \sum_{j=1}^{2}\left\{\operatorname{Pr}\left(\eta_{j} \mid \alpha_{i}\right) \cdot \Phi\left(z_{i t} \gamma+\eta_{j}\right)\right\}}{\sum_{j=1}^{2} \operatorname{Pr}\left(\eta_{j}\right) \cdot \Phi\left(z_{i t} \gamma+\eta_{j}\right)} d \alpha_{i}
\end{aligned}
$$




$$
\begin{aligned}
& =\sum_{k=1}^{2} \alpha_{k} \cdot \frac{\operatorname{Pr}\left(\alpha_{k}\right) \cdot \sum_{j=1}^{2}\left\{\operatorname{Pr}\left(\eta_{j} \mid \alpha_{k}\right) \cdot \Phi\left(z_{i t} \gamma+\eta_{j}\right)\right\}}{\sum_{j=1}^{2} \operatorname{Pr}\left(\eta_{j}\right) \cdot \Phi\left(z_{i t} \gamma+\eta_{j}\right)} \\
& =\sum_{k=1}^{2} \alpha_{k} \cdot \frac{\sum_{j=1}^{2}\left\{\operatorname{Pr}\left(\eta_{j}, \alpha_{k}\right) \cdot \Phi\left(z_{i t} \gamma+\eta_{j}\right)\right\}}{\sum_{j=1}^{2} \operatorname{Pr}\left(\eta_{j}\right) \cdot \Phi\left(z_{i t} \gamma+\eta_{j}\right)}
\end{aligned}
$$

where

$$
\operatorname{Pr}\left(\eta_{j} \mid \alpha_{k}\right)=\frac{\operatorname{Pr}\left(\eta_{j}, \alpha_{k}\right)}{\operatorname{Pr}\left(\alpha_{k}\right)}
$$

\section{Appendix C}

Table $\mathrm{C} 1$ shows the wage coefficients from estimating alternative specifications of the wage model. In Column 1, OLS coefficients are shown which are based on the pooled sample of immigrants with observed wage rates without any corrections for sample selection due to nonparticipation in the labour market. Column 2 shows the results from OLS estimations on the pooled sample including the two-step Heckman selection procedure, see Heckman (1979), where the estimated variable Lambda is included to control for selection effects. Finally, Column 3 shows the coefficients from the estimation of the random effect model with selectivity correction.

The selection effects due to missing observations on wages for non-employed and self-employed individuals are represented by the coefficients to the variable Lambda in Columns 2 and 4 . These coefficients turn out to be highly significant. Thus, it is important to control for this selection and the relatively large changes in coefficients between the simple OLS and the OLS with selection correction confirm this result. In particular, some of the coefficients to the indicator variables for native country change significantly, possibly reflecting that the fraction who are employed and the selection process varies considerably between immigrant groups. The same holds for the 'years since migration' variables. This may partly explain why the only earlier Danish study of wage assimilation, see Ministry of Economics (1997) which did not correct for selectivity (or unobserved heterogeneity) found a clear evidence of wage assimilation while the results in our study are more mixed.

Comparing the random effect estimates with the OLS estimates, the random effect estimates of return to education acquired in Denmark generally tend to increase when unobserved heterogeneity and cohort effects are controlled for. The OLS estimates on the pooled sample give the rather surprising result that the immigrants in Denmark, except immigrants with a Danish university degree, do not get any or even a negative return to educational investments undertaken in Denmark. These results are changed considerably when controlling for unobserved individual effects. 
Table C1. Coefficients from wage estimations for immigrant men. 'Classical Assimilation Model'. Alternative econometric specifications. Dependent variable log hourly wage rate in DKK 1995-prices.

\begin{tabular}{|c|c|c|c|c|c|c|}
\hline & \multicolumn{3}{|c|}{ Refugees } & \multicolumn{3}{|c|}{$\begin{array}{c}\text { Non- } \\
\text { refugees }\end{array}$} \\
\hline & $\begin{array}{l}\text { OLS, } \\
\text { pooled } \\
\text { sample }\end{array}$ & $\begin{array}{c}\text { OLS, } \\
\text { pooled } \\
\text { sample, } \\
\text { Selection } \\
\text { correction }\end{array}$ & $\begin{array}{l}\text { Random } \\
\text { effect, } \\
\text { selection } \\
\text { correction }\end{array}$ & $\begin{array}{c}\text { OLS, } \\
\text { pooled } \\
\text { sample }\end{array}$ & $\begin{array}{c}\text { OLS, } \\
\text { pooled } \\
\text { sample, } \\
\text { selection } \\
\text { correction }\end{array}$ & $\begin{array}{l}\text { Random } \\
\text { effect, } \\
\text { selection } \\
\text { correction }\end{array}$ \\
\hline Constant 1 & $\begin{array}{c}4.648 \\
(0.053)\end{array}$ & $\begin{array}{c}4.863 \\
(0.067)\end{array}$ & $\begin{array}{c}4.981 \\
(0.034)\end{array}$ & $\begin{array}{c}4.436 \\
(0.025)\end{array}$ & $\begin{array}{c}4.614 \\
(0.042)\end{array}$ & $\begin{array}{c}4.528 \\
(0.029)\end{array}$ \\
\hline Constant2 & - & - & $\begin{array}{c}5.385 \\
(0.034)\end{array}$ & - & - & $\begin{array}{c}5.051 \\
(0.029)\end{array}$ \\
\hline \multicolumn{7}{|l|}{ Country of origin ${ }^{1}$ : } \\
\hline EU countries (12) & - & - & - & $\begin{array}{l}-0.092 \\
(0.008)\end{array}$ & $\begin{array}{l}-0.120 \\
(0.009)\end{array}$ & $\begin{array}{l}-0.075 \\
(0.005)\end{array}$ \\
\hline Turkey & - & - & - & $\begin{array}{l}-0.087 \\
(0.010)\end{array}$ & $\begin{array}{l}-0.047 \\
(0.012)\end{array}$ & $\begin{array}{c}0.007 \\
(0.007)\end{array}$ \\
\hline Other Europan countries & $\begin{array}{c}0.096 \\
(0.009)\end{array}$ & $\begin{array}{c}0.052 \\
(0.013)\end{array}$ & $\begin{array}{c}0.015 \\
(0.007)\end{array}$ & $\begin{array}{c}-0.069 \\
(0.011)\end{array}$ & $\begin{array}{l}-0.059 \\
(0.011)\end{array}$ & $\begin{array}{l}-0.003 \\
(0.007)\end{array}$ \\
\hline Africa & $\begin{array}{r}-0.048 \\
(0.020)\end{array}$ & $\begin{array}{r}-0.005 \\
(0.021)\end{array}$ & $\begin{array}{r}-0.008 \\
(0.017)\end{array}$ & $\begin{array}{l}-0.167 \\
(0.011)\end{array}$ & $\begin{array}{l}-0.123 \\
(0.013)\end{array}$ & $\begin{array}{l}-0.068 \\
(0.007)\end{array}$ \\
\hline North America & - & - & - & $\begin{array}{l}-0.037 \\
(0.014)\end{array}$ & $\begin{array}{l}-0.017 \\
(0.014)\end{array}$ & $\begin{array}{c}0.039 \\
(0.008)\end{array}$ \\
\hline South \& Latin America & $\begin{array}{c}0.045 \\
(0.014)\end{array}$ & $\begin{array}{r}-0.010 \\
(0.018)\end{array}$ & $\begin{array}{r}-0.058 \\
(0.011)\end{array}$ & $\begin{array}{l}-0.101 \\
(0.021)\end{array}$ & $\begin{array}{l}-0.054 \\
(0.022)\end{array}$ & $\begin{array}{l}-0.050 \\
(0.016)\end{array}$ \\
\hline Sri Lanka, Iran \& Iraq & - & - & - & $\begin{array}{l}-0.238 \\
(0.046)\end{array}$ & $\begin{array}{l}-0.255 \\
(0.046)\end{array}$ & $\begin{array}{l}-0.306 \\
(0.036)\end{array}$ \\
\hline Vietnam & $\begin{array}{r}-0.014 \\
(0.009)\end{array}$ & $\begin{array}{r}-0.049 \\
(0.011)\end{array}$ & $\begin{array}{c}-0.091 \\
(0.007)\end{array}$ & - & - & - \\
\hline Pakistan & - & - & - & $\begin{array}{l}-0.136 \\
(0.013)\end{array}$ & $\begin{array}{l}-0.099 \\
(0.014)\end{array}$ & $\begin{array}{l}-0.055 \\
(0.008)\end{array}$ \\
\hline No citizenship & $\begin{array}{r}-0.013 \\
(0.011)\end{array}$ & $\begin{array}{c}0.042 \\
(0.015)\end{array}$ & $\begin{array}{c}0.068 \\
(0.009)\end{array}$ & - & - & - \\
\hline Others & $\begin{array}{r}-0.122 \\
(0.036)\end{array}$ & $\begin{array}{r}-0.089 \\
(0.037)\end{array}$ & $\begin{array}{r}-0.031 \\
(0.022)\end{array}$ & $\begin{array}{l}-0.141 \\
(0.011)\end{array}$ & $\begin{array}{l}-0.112 \\
(0.012)\end{array}$ & $\begin{array}{l}-0.074 \\
(0.007)\end{array}$ \\
\hline \multicolumn{7}{|l|}{ Educational indicators ${ }^{2}$ : } \\
\hline Education, primary & $\begin{array}{r}-0.087 \\
(0.013)\end{array}$ & $\begin{array}{l}-0.077 \\
(0.013)\end{array}$ & $\begin{array}{l}-0.057 \\
(0.010)\end{array}$ & $\begin{array}{c}-0.018 \\
(0.009)\end{array}$ & $\begin{array}{l}-0.003 \\
(0.009)\end{array}$ & $\begin{array}{c}0.013 \\
(0.006)\end{array}$ \\
\hline Education, secondary & $\begin{array}{c}0.024 \\
(0.019)\end{array}$ & $\begin{array}{c}0.032 \\
(0.020)\end{array}$ & $\begin{array}{c}0.003 \\
(0.013)\end{array}$ & $\begin{array}{l}-0.043 \\
(0.022)\end{array}$ & $\begin{array}{l}-0.037 \\
(0.022)\end{array}$ & $\begin{array}{l}-0.052 \\
(0.017)\end{array}$ \\
\hline Education, vocational & $\begin{array}{r}-0.042 \\
(0.010)\end{array}$ & $\begin{array}{r}-0.066 \\
(0.011)\end{array}$ & $\begin{array}{r}-0.070 \\
(0.009)\end{array}$ & $\begin{array}{l}-0.018 \\
(0.012)\end{array}$ & $\begin{array}{l}-0.057 \\
(0.013)\end{array}$ & $\begin{array}{l}-0.027 \\
(0.008)\end{array}$ \\
\hline Education, theoretical 1 & $\begin{array}{r}-0.055 \\
(0.022)\end{array}$ & $\begin{array}{r}-0.066 \\
(0.022)\end{array}$ & $\begin{array}{c}0.009 \\
(0.024)\end{array}$ & $\begin{array}{l}-0.164 \\
(0.018)\end{array}$ & $\begin{array}{l}-0.249 \\
(0.021)\end{array}$ & $\begin{array}{l}-0.122 \\
(0.014)\end{array}$ \\
\hline Education, theoretical 2 & $\begin{array}{c}0.082 \\
(0.019)\end{array}$ & $\begin{array}{c}0.073 \\
(0.019)\end{array}$ & $\begin{array}{c}0.121 \\
(0.017)\end{array}$ & $\begin{array}{l}-0.005 \\
(0.016)\end{array}$ & $\begin{array}{l}-0.080 \\
(0.019)\end{array}$ & $\begin{array}{c}0.035 \\
(0.010)\end{array}$ \\
\hline Education, theoretical 3 & $\begin{array}{c}0.167 \\
(0.023)\end{array}$ & $\begin{array}{c}0.123 \\
(0.024)\end{array}$ & $\begin{array}{c}0.158 \\
(0.024)\end{array}$ & $\begin{array}{c}0.084 \\
(0.014)\end{array}$ & $\begin{array}{c}0.018 \\
(0.017)\end{array}$ & $\begin{array}{c}0.119 \\
(0.009)\end{array}$ \\
\hline $\mathrm{YSM} / 100^{3}$ & $\begin{array}{c}0.442 \\
(0.359)\end{array}$ & $\begin{array}{r}-3.207 \\
(0.784)\end{array}$ & $\begin{array}{c}-5.473 \\
(0.296)\end{array}$ & $\begin{array}{c}0.278 \\
(0.271)\end{array}$ & $\begin{array}{l}-1.094 \\
(0.033)\end{array}$ & $\begin{array}{l}-0.621 \\
(0.205)\end{array}$ \\
\hline YSM (5+ years) $/ 100^{3}$ & $\begin{array}{c}0.356 \\
(0.497)\end{array}$ & $\begin{array}{c}3.515 \\
(0.782)\end{array}$ & $\begin{array}{c}5.413 \\
(0.423)\end{array}$ & $\begin{array}{l}-0.480 \\
(0.405)\end{array}$ & $\begin{array}{c}0.890 \\
(0.447)\end{array}$ & $\begin{array}{c}0.729 \\
(0.308)\end{array}$ \\
\hline YSM (10+ years) $/ 100^{3}$ & $\begin{array}{c}0.660 \\
(0.317)\end{array}$ & $\begin{array}{c}1.456 \\
(0.351)\end{array}$ & $\begin{array}{c}1.999 \\
(0.284)\end{array}$ & $\begin{array}{c}0.585 \\
(0.246)\end{array}$ & $\begin{array}{c}1.058 \\
(0.254)\end{array}$ & $\begin{array}{c}0.681 \\
(0.183)\end{array}$ \\
\hline
\end{tabular}




\begin{tabular}{|c|c|c|c|c|c|c|}
\hline Age /100 & $\begin{array}{c}0.426 \\
(0.282)\end{array}$ & $\begin{array}{c}0.478 \\
(0.282)\end{array}$ & $\begin{array}{c}0.546 \\
(0.148)\end{array}$ & $\begin{array}{c}2.471 \\
(0.219)\end{array}$ & $\begin{array}{c}1.828 \\
(0.236)\end{array}$ & $\begin{array}{c}1.572 \\
(0.139)\end{array}$ \\
\hline Age, squared /10000 & $\begin{array}{r}-0.295 \\
(0.385)\end{array}$ & $\begin{array}{c}0.004 \\
(0.388)\end{array}$ & $\begin{array}{r}-0.100 \\
(0.198)\end{array}$ & $\begin{array}{l}-2.414 \\
(0.290)\end{array}$ & $\begin{array}{l}-1.145 \\
(0.339)\end{array}$ & $\begin{array}{l}-1.150 \\
(0.177)\end{array}$ \\
\hline $\mathrm{UIM}^{4}$ & $\begin{array}{c}0.048 \\
(0.196)\end{array}$ & $\begin{array}{c}0.848 \\
(0.248)\end{array}$ & $\begin{array}{c}0.998 \\
(0.170)\end{array}$ & $\begin{array}{c}0.001 \\
(0.124)\end{array}$ & $\begin{array}{c}1.078 \\
(0.194)\end{array}$ & $\begin{array}{c}1.101 \\
(0.084)\end{array}$ \\
\hline Single & $\begin{array}{r}-0.019 \\
(0.007)\end{array}$ & $\begin{array}{r}-0.005 \\
(0.007)\end{array}$ & $\begin{array}{c}0.010 \\
(0.006)\end{array}$ & $\begin{array}{l}-0.065 \\
(0.006)\end{array}$ & $\begin{array}{c}0.005 \\
(0.011)\end{array}$ & $\begin{array}{c}0.002 \\
(0.004)\end{array}$ \\
\hline \multicolumn{7}{|l|}{ Occupational category $^{5}$ : } \\
\hline Manager or high level salaried worker & $\begin{array}{c}0.108 \\
(0.011)\end{array}$ & $\begin{array}{c}0.108 \\
(0.011)\end{array}$ & $\begin{array}{c}0.034 \\
(0.008)\end{array}$ & $\begin{array}{c}0.216 \\
(0.008)\end{array}$ & $\begin{array}{c}0.215 \\
(0.008)\end{array}$ & $\begin{array}{c}0.088 \\
(0.005)\end{array}$ \\
\hline Salaried worker, low level & $\begin{array}{r}-0.054 \\
(0.011)\end{array}$ & $\begin{array}{r}-0.056 \\
(0.011)\end{array}$ & $\begin{array}{r}-0.054 \\
(0.009)\end{array}$ & $\begin{array}{c}0.011 \\
(0.009)\end{array}$ & $\begin{array}{c}0.011 \\
(0.009)\end{array}$ & $\begin{array}{l}-0.016 \\
(0.006)\end{array}$ \\
\hline Skilled & $\begin{array}{c}0.061 \\
(0.010)\end{array}$ & $\begin{array}{c}0.061 \\
(0.010)\end{array}$ & $\begin{array}{c}0.052 \\
(0.008)\end{array}$ & $\begin{array}{c}0.029 \\
(0.008)\end{array}$ & $\begin{array}{c}0.027 \\
(0.008)\end{array}$ & $\begin{array}{c}0.012 \\
(0.006)\end{array}$ \\
\hline Missing occupation & $\begin{array}{r}-0.160 \\
(0.009)\end{array}$ & $\begin{array}{r}-0.159 \\
(0.009)\end{array}$ & $\begin{array}{r}-0.105 \\
(0.006)\end{array}$ & $\begin{array}{l}-0.035 \\
(0.009)\end{array}$ & $\begin{array}{l}-0.035 \\
(0.009)\end{array}$ & $\begin{array}{l}-0.098 \\
(0.005)\end{array}$ \\
\hline Lambda, $\lambda$ & - & $\begin{array}{r}-0.198 \\
(0.038) \\
\end{array}$ & - & - & $\begin{array}{l}-0.374 \\
(0.052) \\
\end{array}$ & - \\
\hline $\begin{array}{l}\text { Number of observations with an } \\
\text { observed hourly wage rate }\end{array}$ & 12724 & 12724 & 12724 & 25380 & 25830 & 25830 \\
\hline $\begin{array}{l}\text { Number of observations in employment } \\
\text { relation }\end{array}$ & 44897 & 44897 & 44897 & 48887 & 48887 & 48887 \\
\hline $\mathrm{R} 2$ & 0.168 & 0.170 & - & 0.135 & 0.137 & - \\
\hline Mean log-likelihood ${ }^{6}$ & - & - & -0.615 & - & - & -0.716 \\
\hline
\end{tabular}

1. Excluded category for refugees is Sri Lanka, Iran and Iraq and excluded category for non-refugees is other Nordic countries. 2. Excluded category is 'primary education' for Danish born individuals and 'no education in Denmark' for immigrants.

3. YSM is years since migration.

4. UIM is unemployment in the year of entering the Danish labour market..

5. Excluded category is 'unskilled worker'.

6. The log-likelihood for the joint wage and employment random effect model. The estimated probabilities of the constant terms are shown in Table 4. 